\title{
Structure and function of a novel antioxidant peptide from the skin of tropical frogs
}

\author{
Eder Alves Barbosa $^{\mathrm{a}, \mathrm{b}}$, Ana Oliveira ${ }^{\mathrm{c}}$, Alexandra Plácido ${ }^{\mathrm{d}}$, Renato Socodato ${ }^{\mathrm{e}}$, Camila C. Portugal $^{\mathrm{e}}$, \\ Ana Carolina Mafud ${ }^{\mathrm{f}, \mathrm{g}}$, Alicia S. Ombredane ${ }^{\mathrm{h}}$, Daniel C. Moreira ${ }^{\mathrm{i}}$, Nuno Vale ${ }^{\mathrm{j}}$, Lucinda J. Bessa ${ }^{\mathrm{k}}$, \\ Graziella A. Joanitti ${ }^{\mathrm{h}, \mathrm{l}}$, Cláudia Alves ${ }^{\mathrm{k}}$, Paula Gomes ${ }^{\mathrm{k}}$, Cristina Delerue-Matos ${ }^{\mathrm{d}}$, \\ Yvonne Primerano Mascarenhas ${ }^{\mathrm{f}}$, Mariela M. Marani ${ }^{\mathrm{m}}$, João B. Relvas ${ }^{\mathrm{e}}$, Manuela Pintado ${ }^{\mathrm{c}}$, \\ José Roberto S.A. Leite ${ }^{\mathrm{e}, \mathrm{i}, *}$
}

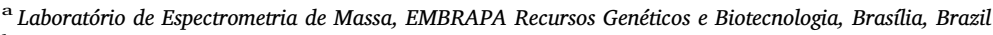

${ }^{\mathrm{b}}$ Laboratório de Síntese e Análise de Biomoléculas, Instituto de Química, Universidade de Brasília, Brasília, Brazil

' Centro de Biotecnologia e Química Fina, CBQF, Universidade Católica Portuguesa, Rua Arquiteto Lobão Vital Apartado, 2511, Asprela, Porto, Portugal

' $L A Q V / R E Q U I M T E$, GRAQ, Instituto Superior de Engenha do Porto, ISEP, Porto, Portugal

e Glial Cell Biology Lab, Instituto de Investigação e Inovação em Saúde and Instituto de Biologia Molecular e Celular, Universidade do Porto, Porto, Portugal

${ }^{\mathrm{f}}$ Instituto de Física de São Carlos, IFSC, Universidade de São Paulo, USP, São Carlos, SP, Brazil

${ }^{\mathrm{g}}$ Dept Medical Parasitology and Infection Biology, Swiss Tropical and Public Health Institute, Basel 4051, Switzerland

${ }^{\text {h }}$ Laboratório de Nanobiotecnologia, Instituto de Biologia, Campus Darcy Ribeiro, UnB, Brasília, DF, Brazil

i Área de Morfologia, Faculdade de Medicina, Universidade de Brasília, UnB, Brasília, DF, Brazil

${ }^{\mathrm{j}}$ UCIBIO/REQUIMTE, Laboratório de Farmacologia, Departamento de Ciências do Medicamento, Faculdade de Farmácia da Universidade do Porto, Rua de Jorge Viterbo Ferreira, 228, 4050-313 Porto, Portugal

${ }^{\mathrm{k}}$ LAQV/REQUIMTE, Departamento de Química e Bioquímica, Faculdade de Ciências da Universidade do Porto, Rua do Campo Alegre, 687, 4169-007 Porto, Portugal

${ }^{1}$ Campus Ceilândia, Centro Metropolitano, UnB, Ceilândia, Brasília, DF, Brazil

${ }^{\mathrm{m}}$ IPEEC-CONICET, Consejo Nacional de Investigaciones Científicas y Técnicas, Puerto Madryn, Argentina

\begin{abstract}
A B S T R A C T
The amphibian skin plays an important role protecting the organism from external harmful factors such as microorganisms or UV radiation. Based on biorational strategies, many studies have investigated the cutaneous secretion of anurans as a source of bioactive molecules. By a peptidomic approach, a novel antioxidant peptide (AOP) with in vitro free radical scavenging ability was isolated from Physalaemus nattereri. The AOP, named antioxidin-I, has a molecular weight $[\mathrm{M}+\mathrm{H}]^{+}=1543.69 \mathrm{Da}$ and a TWYFITPYIPDK primary amino acid sequence. The gene encoding the antioxidin-I precursor was expressed in the skin tissue of three other Tropical frog species: Phyllomedusa tarsius, P. distincta and Pithecopus rohdei. cDNA sequencing revealed highly homologous regions (signal peptide and acidic region). Mature antioxidin-I has a novel primary sequence with low similarity compared with previously described amphibian's AOPs. Antioxidin-I adopts a random structure even at high concentrations of hydrophobic solvent, it has poor antimicrobial activity and poor performance in free radical scavenging assays in vitro, with the exception of the ORAC assay. However, antioxidin-I presented a low cytotoxicity and suppressed menadione-induced redox imbalance when tested with fibroblast in culture. In addition, it had the capacity to substantially attenuate the hypoxia-induced production of reactive oxygen species when tested in hypoxia exposed living microglial cells, suggesting a potential neuroprotective role for this peptide.
\end{abstract}

Keywords:

Amphibia

Antioxidant peptide

Antioxidin

Microglia

Reactive oxygen species

Skin secretion

\section{Introduction}

Amphibian's skin constitutes a water and gas permeable thin barrier between the organism and the environment. Physiological skin roles include gas exchange, excretion, thermoregulation, and reproduction [1]. Additionally, the amphibian skin presents an important defensive function against predators, bacteria and fungi. These are particularly relevant in the light of the natural history of amphibians. Most amphibians inhabit moist or aquatic habitats and the constantly humid skin represents an adequate media for bacterial and fungal growth. Over the last decades, one of the most investigated features of the amphibian's skin was related to the innate immune system. Amphibian

\footnotetext{
* Correspondence to: Universidade de Brasília (UnB), Faculdade de Medicina, Campus Universitário Darcy Ribeiro, Asa Norte, Brasília, DF CEP 70910-900, Brasil.

E-mail addresses: jrsaleite@gmail.com, jrleite@pq.cnpq.br (J.R.S.A. Leite).
} 
species developed a protection mechanism based on the production and storage of antimicrobial peptides by specialized granular glands spread throughout the skin that protects skin tissue against microorganism infection [2]. These glands also produce a set of biomolecules having distinct structures and well-established activities e.g. vasodilatation, hypotension [3,4] and endopeptidase inhibition [5]. This molecular arsenal protects these animals not only from microorganisms but also from predators and other abiotic threats [6].

By employing a biorational approach (i.e. predict the presence of compounds with potential pharmacological applications based on organisms' interactions with the environment) a great number of bioactive molecules from amphibian skin have been described, most of them with, but not limited to, antimicrobial activity [7]. Many amphibians transit between aquatic and terrestrial habitats, which expose the animal's skin to wide variations in $\mathrm{O}_{2}$ availability. Moreover, during day light the delicate amphibian skin, lacking an external protective layer and with a thin stratum corneum, is exposed to UV radiation. Both, UV exposure and drastic changes in $\mathrm{O}_{2}$ exposure have been linked with altered reactive oxygen species (ROS) generation. Therefore, it could be predicted, using a biorational approach, that amphibian skin secretion would have a molecular mechanism to minimize the threat from these sources. Pheomelanin, a melanin type protein, present in the skin of Hymenochirus boettgeri, is an example of a protector molecule against UV light damage in amphibians [8]. Indeed, a collection of peptides with antioxidant activity in chemical systems isolated from the skin secretion of Asiatic frogs has been recently reported [9-11]. In general, a great variability of structures was found among the species studied $[9,10,12]$, suggesting that these peptides did not arise from a common ancestor molecule.

In biological systems, antioxidant networks manage the steady state of reactive species [13]. Reactive species, including ROS, are important signals that participate in many physiological processes [14-16]. There are several cellular pathways that lead to ROS production, including mitochondrial electron transport chain, NADPH oxidases and several other enzymatic reactions (e.g. oxidases) [13]. The rate of ROS formation from such sources responds intra and extracellular stimuli. For example, hypoxia exposure [17] and reperfusion after an ischemic event [18] elicit an overproduction of mitochondrial ROS. Thus, the constantly produced ROS and their control by antioxidants constitute a redox signaling mechanism, in which reversible oxidation of endogenous thiols has a central role [19]. In some situations, excess ROS may overcome the management capacity of antioxidants, leading to a redox imbalance. Due to their reactivity, excess ROS may cause irreversible oxidative damage to biomolecules, which may have signaling functions, but also cause loss of function [20]. The disruption of signaling pathways and accumulation of oxidatively modified molecules have been linked to several neurodegenerative disorders, such as Alzheimer's disease [21], Parkinson's disease [22], Huntington disease [23] and Amyotrophic Lateral Sclerosis [24].

In this work, we predicted the presence of peptides with antioxidant activity in the cutaneous secretion from the tropical frog Physalaemus nattereri (Steindachner, 1863). We used chromatography, tandem mass spectrometry, molecular biology and in silico techniques followed by in vitro assays to characterize antioxidin-I, a peptide isolated from the tropical frog $P$. nattereri with potential antioxidant activity. We demonstrated the expression of this peptide in other tropical frogs of the Phyllomedusa and Pithecopus genus: Phyllomedusa tarsius, $P$. distincta and Pithecopus rohdei. Then, aiming at the potential pharmaceutical use of this peptide, we conducted viability and antioxidant assays in cell culture. We tested the ability of the peptide to mitigate menadioneinduced redox imbalance in fibroblasts and the capacity to suppress ROS levels in hypoxia-exposed microglia.

\section{Material and methods}

\subsection{Isolation and characterization of the antioxidin-I}

Adult Phyllomedusa distincta, P. tarsius, Pithecopus rohdei (first assessed under the generic name Phyllomedusa, but has been transferred to the genus Pithecopus by Duellman et al. [25]) and Physalaemus nattereri specimens were captured manually in the Brazilian Atlantic forest of Santa Catarina and São Paulo, Tropical forest of Amazônia and Cerrado of Goiás, respectively, under the license $N^{\circ} 240 / 2005$-CGFAU from the Instituto Brasileiro e dos Recursos Renováveis - IBAMA (Process No. 034/06-COFAN). The cutaneous secretion from Physalaemus nattereri was obtained by electrical stimulation $(6 \mathrm{~V})$, collected with Milli-Q water in $50 \mathrm{~mL}$ tubes, filtrated (Millipore filters, $0.22 \mu \mathrm{m}$ ) and immediate frozen and lyophilized.

The $P$. nattereri dry secretion $(1 \mathrm{mg}$ ) was dissolved in Milli-Q water $(500 \mu \mathrm{L})$ and subjected to an HPLC system (Shimadzu Co., LC-20 CE model), using a Vydac C18 reverse phase column (2018 TP). The fractions were eluted with a linear gradient of $0.1 \%(\mathrm{v} / \mathrm{v})$ TFA/acetonitrile ranging from $5 \%$ to $60 \%$ over $60 \mathrm{~min}$ and $75-95 \%$ over $5 \mathrm{~min}$ at a flow rate of $1 \mathrm{~mL} / \mathrm{min}$. Fractions were monitored at 216 and $280 \mathrm{~nm}$, collected in tubes and dried under vacuum centrifugation.

Dried fractions were re-dissolved in Milli-Q water. The amount of solvent, ranged from 10 to $100 \mu \mathrm{L}$, was adjust according to the absorbance value previously obtained for each fraction. One microliter aliquot of the chromatographic fractions was dissolved in $\alpha$-cyano-4-hydroxicinamic acid matrix solution (1:3, v/v) and then applied on the MALDI plate. The molecular mass of the peptides was determined by MALDI-TOF/MS using the UltraFlex Xtreme mass spectrometer (Bruker Daltonics) in the positive reflected mode, controlled by the FlexControl software. The ions of interest were fragmented in the LIFT mode (MS/ MS), aiming the de novo sequencing of peptides. Before each analysis, the spectrometer was calibrated using a mixture of peptides. The spectra were analyzed manually using the FlexAnalysis software (Bruker Daltonics). Amino acid sequencing data were compared with cDNA sequencing analyses.

\section{2. cDNA sequencing}

Three specimens from each amphibian species were euthanized by infusion of $2 \%$ liquid lidocaine hydrochloride solution $(100 \mu \mathrm{L})$ directly into the brain [26]. The dorsal cutaneous tissues were isolated by dissection. The inguinal glands of $P$. nattereri were dissected separately from dorsal skin. Tissues for RNA extraction were immediately frozen in liquid nitrogen and stored at $-80{ }^{\circ} \mathrm{C}$. The cDNA characterization and analysis were performed as previously reported (Brand et al., 2006). Briefly, the isolated tissues were pulverized in liquid nitrogen and approximately $10 \mathrm{mg}$ of the resulted powder were used for extraction of the total RNA using the Trizol reagent (Invitrogen) according to the manufacturer's instructions. One microgram of RNA was subjected to cDNA synthesis with the enzyme ImProm II (Promega), according to the manufacturer's protocol. Degenerate oligonucleotides (Table S1) were used for PCR reactions.

PCR products were run by electrophoresis in $1 \%$ agarose gel for analysis of the amplified fragments. Those having molecular weights between 250 and 400 bp were isolated and purified with Wizard SV Gel and PCR Clean-Up System (Promega), following manufacturer's instructions. The purified DNA samples were subjected to the pGEM-T Easy (Promega) vector binding reaction, according to manufacturer's instructions, and transfected into $E$. coli (DH5 $\alpha$ ) by electroporation. After selecting the clones of interest, the plasmids were isolated and submitted to automatic nucleotide sequencing (Sanger sequencing method). 


\subsection{Relative expression assays by $q P C R$}

The nucleotide sequences of the precursor of interest were used as a template for the design and synthesis of specific oligonucleotides targeting relative gene expression assays by means of real-time PCR (RTPCR), performed as previously reported [6]. Briefly, the total RNA constituting the dorsal cutaneous tissue and the inguinal glands of $P$. nattereri were extracted separately. A fraction of cDNA, synthesized with Oligo-dT, was diluted in nano pure $\mathrm{H}_{2} \mathrm{O}$ (1:25). This solution was used as template in the QPCR assays, which were performed on a 7500 Fast RT-PCR System (Applied Biosystems) in Relative Quantification Plate mode. Platinum SYBR Green qPCR SuperMix-UDG with ROX (Invitrogen) was used in the preparation of reactions, as described by the manufacturer, in which the specific oligonucleotides synthesized were added (Table S1). Expression of the gene encoding the actin protein was used as a normalizer. At the end of each reaction, the dissociation cycle was performed to verify the specificity of the oligonucleotides. The experiment was carried out in triplicate. Statistical analyses of the results were done according to the manual suggested by Applied Biosystems.

\subsection{Density functional theory}

Density Functional Theory (DFT) [27] calculations were performed to optimize the structures. The B3LYP $[28,29]$ exchange-correlation functional was chosen and the basis set used was the 6-311 G with two polarization functions $(\mathrm{d}, \mathrm{p})$ and diffuse functions for hydrogen $\left({ }^{++}\right)$ [30], as implemented in the Gaussian 09 software [31].

\subsection{Peptide synthesis}

Peptide (C-terminal amide) was assembled by Fmoc/tBu solid-phase peptide synthesis (SPPS) methodologies assisted with microwave (MW) energy, using a Liberty Microwave Peptide Synthesizer (CEM Corporation, Mathews, NC, USA). The Rink amide resin was preconditioned for $15 \mathrm{~min}$ in N,N-dimethylformamide (DMF) and then transferred into the MW-reaction vessel. The initial Fmoc deprotection step was carried out using 20\% piperidine in DMF containing $0.1 \mathrm{M}$ of 1-hydroxybenzotriazole (HOBt) in two MW irradiation pulses: $30 \mathrm{~s}$ at $24 \mathrm{~W}$ plus $3 \mathrm{~min}$ at $28 \mathrm{~W}$, in both cases temperature being no higher than $75{ }^{\circ} \mathrm{C}$. The C-terminal amino acid was coupled to the deprotected Rink amide resin, using $5 \mathrm{M}$ equivalents (eq) of the Fmoc-protected amino acid in DMF (0.2 M), 5 eq of 0.5 M HBTU/HOBt in DMF, and 10 eq of $2 \mathrm{M}$ N-ethyl-N,N-diisopropylamine (DIPEA) in N-methylpyrrolidone (NMP). The coupling step was carried out for $5 \mathrm{~min}$ at $35 \mathrm{~W}$ MW irradiation, with the maximum temperature reaching $75^{\circ} \mathrm{C}$. Remaining amino acids were sequentially coupled in the $\mathrm{C} \rightarrow \mathrm{N}$ direction by means of similar deprotection and coupling cycles. Following completion of the sequence assembly, the peptide was released from the resin with concomitant removal of side-chain protecting groups, by a $1.5 \mathrm{~h}$ acidolysis at room temperature using a trifluoroacetic acid (TFA)-based cocktail containing triisopropysilane (TIS) and water (95:2.5:2.5, v/v/ v) as scavengers.

For MS analysis, samples were separated on an HPLC Accela (Thermo Fischer Scientific, Bremen, Germany) with a C18 Nucleodur gravity column (Macherey-Nagel, USA) $(5 \mu \mathrm{m} 4 \mathrm{~mm} \times 125 \mathrm{~mm})$ using a gradient of $\mathrm{CH}_{3} \mathrm{CN}$. Starting with $100 \%$ solvent $\mathrm{A}\left(\mathrm{H}_{2} \mathrm{O} / 0.1 \%\right.$ (v/v) TFA) and rising to $100 \%$ Solvent $\mathrm{B}\left(\mathrm{CH}_{3} \mathrm{CN}\right)$ over $30 \mathrm{~min}$ at a flow rate of $1.0 \mathrm{~mL} / \mathrm{min}$. MS analysis was performed on an LTQ OrbitrapTM XL hybrid mass spectrometer (Thermo Fischer Scientific, Bremen, Germany) controlled by LTQ Tune Plus 2.5.5 and Xcalibur 2.1.0. Electrospray ionization source settings (ESI) were as follows: source voltage, $3.1 \mathrm{kV}$; the capillary temperature was $275^{\circ} \mathrm{C}$ with a sheath gas flow rate at 40 and auxiliary gas flow rate at 10 (arbitrary unit as provided by the software settings). The capillary voltage was $36 \mathrm{~V}$ and the tube lens voltage $110 \mathrm{~V}$. MS data handling software (Xcalibur
QualBrowser software, Thermo Fischer Scientific) was used to obtain the confirmation of the synthetic peptide by their exact $m / z$ value.

Peptides purity were determined by HPLC, using a Hitachi-Merck LaChrom Elite system equipped with a quaternary pump, a temperature controlled automated sampler, and a diode-array detector (DAD). Peptides were purified by preparative HPLC system (LaPrep Sigma), with LP1100 Quaternary LPG pump injection with fractionation valve, using $0.05 \%$ TFA water solution/ $\mathrm{CH}_{3} \mathrm{CN}$ mixtures as the mobile phase. Both peptides were obtained with correct mass spectra data and high chromatographic purity.

\subsection{Sequence analysis}

The peptide sequence obtained was compared with the antimicrobial peptide deposited at the antimicrobial peptide database [32]. The program ProtParam was used for computation of physical and chemical parameters (MW, theoretical pI, instability index, aliphatic index, and grand average of hydropathicity, GRAVY). The HeliQuest program was used to calculate hydrophobic moments $(\mu \mathrm{H})$ and helix wheel projections.

\subsection{Structural studies}

Three-dimensional structural model predictions of the peptides were obtained using the internet resources PEP-FOLD. Secondary structure content was studied by circular dichroism spectroscopy in the far UV wavelengths, using a JASCO J 815 instrument (Jasco Corp., Tokyo, Japan). The measurements were performed under nitrogen gas flow of $8 \mathrm{~L} / \mathrm{h}$ at $20^{\circ} \mathrm{C}$, controlled by a Peltier system (JASCO). Spectra were recorded between 190 and $260 \mathrm{~nm}$, using a $100 \mathrm{~mm}$ cell path length. The peptides were dissolved in either Milli-Q water or 2,2,2trifluoethanol (TFE) $(10,20$ or $40 \%)$ at $80 \mu \mathrm{M}$ final concentration. The instrument was set at $50 \mathrm{~nm} / \mathrm{min}$ scan speed, $1 \mathrm{~s}$ response time and $1 \mathrm{~nm}$ bandwidth. The spectra were converted to molar ellipticity residue half by using the relationship: [ $\theta] / \theta(10 \times \mathrm{c} \times \mathrm{n} \times \mathrm{d})$, where [ $\theta]$ is the molar ellipticity (in degrees $\times \mathrm{cm}^{2} \times \mathrm{dmol}^{-1}$ ), $\theta$ the ellipticity in mill degrees, $\mathrm{n}$ is the number of peptide bonds, $\mathrm{c}$ is the molar concentration, $d$ is the length of the cell in centimeters.

\subsection{Assessment of antimicrobial activity}

Antioxidin-I and antioxidin-RP1 (control) peptides were screened for antibacterial activity against four reference strains, Escherichia coli ATCC 25922, Pseudomonas aeruginosa ATCC 27853, Staphylococcus aureus ATCC 25923 and Enterococcus faecalis ATCC 29212. Minimum inhibitory concentrations (MICs) were determined using a broth microdilution technique, following the recommendations of the Clinical and Laboratory Standards Institute (CLSI, 2012). Stock peptide solutions $(10 \mathrm{mg} / \mathrm{mL})$ were diluted in Mueller-Hinton broth (MHB-BioKar Diagnostics, Allonne, France) to achieve concentrations ranging from 4 to $1024 \mu \mathrm{g} / \mathrm{mL}$. Each bacterial inoculum was prepared in MHB and standardized in order to obtain a final concentration of $5 \times 10^{5} \mathrm{CFU} /$ $\mathrm{mL}$. Inoculated 96 -well plates were incubated at $37^{\circ} \mathrm{C}$ for $20-24 \mathrm{~h}$. The MIC was defined as the lowest concentration of the peptide inhibiting the visible growth. If a MIC value was within the range of concentrations tested, then the minimum bactericidal concentration (MBC) was determined by spreading on Mueller-Hinton agar an aliquot of $10 \mu \mathrm{L}$ from all wells in which no visible bacterial growth was observed, with further incubation for $24 \mathrm{~h}$ at $37^{\circ} \mathrm{C}$. The lowest concentration at which no growth occurred on the agar plates was defined as the MBC [33]. Two independent experiments were performed.

\subsection{In vitro radical scavenging assays}

\subsubsection{ABTS assay}

Free radical scavenging activity was determined by 2,2-azinobis-3- 
ethylbenzothiazoline-6-sulphonic acid (ABTS ${ }^{+}$) method as described by Gião et al. [34]. To oxidize the colorless ABTS to the blue-green $\mathrm{ABTS}^{+}$ radical cation, ABTS $(7 \mathrm{mM})$ was mixed with potassium persulfate $(2.45 \mathrm{mM})$ and kept for $12-16 \mathrm{~h}$ at room temperature in the dark. The ABTS solution was diluted with water to an absorbance of 0.70 ( \pm 0.02 ) at $734 \mathrm{~nm}$ (Shimadzu $1240 \mathrm{UV}$-visible spectrophotometer). The absorbance reading was exactly 6 min after initial mixing of $1.0 \mathrm{~mL}$ of diluted $\mathrm{ABTS}^{+}$with $10 \mu \mathrm{L}$ of peptide solution previously prepared at $0.5 \mathrm{mg} / \mathrm{mL}$ for antioxidin-RP1 and at $2 \mathrm{mg} / \mathrm{mL}$ for antioxidin-I both in Milli-Q water. The inhibition (\%) of the sample was compared with a standard curve made from the corresponding readings of trolox (6-hydroxy-2,5,7,8-tetramethylchroman-2-carboxylic acid) solutions at different concentrations $(20-200 \mu \mathrm{g} / \mathrm{mL})$ and the results were expressed as $\mathrm{mg}$ of trolox equivalents/mg peptide.

\subsubsection{DPPH assay}

A stock solution of 1,1-diphenyl-2-picrylhydrazyl ( $\alpha, \alpha$-diphenylbpicrylhydrazyl; DPPH) was prepared in methanol at $60 \mu \mathrm{M}$ and checked by measuring an absorbance of $0.6( \pm 0.02)$ at $515 \mathrm{~nm}$ (Shimadzu 1240 UV-visible spectrophotometer). The peptides were dissolved in Milli-Q water at $0.5 \mathrm{mg} / \mathrm{mL}$ for antioxidin-RP1 and at $2 \mathrm{mg} / \mathrm{mL}$ for antioxidin-I. Each peptide sample $(0.25 \mathrm{~mL})$ was mixed with $1.75 \mathrm{~mL}$ of DPPH and the reaction tubes, in triplicates, were kept at $25{ }^{\circ} \mathrm{C}$ for $30 \mathrm{~min}$ in dark. A negative control was performed with Milli-Q water $(0.25 \mathrm{~mL})$ dissolved in $1.75 \mathrm{~mL}$ of DPPH and kept under the same conditions as samples. Spectrophotometric measurements were done at $515 \mathrm{~nm}$ [35]. The inhibition (\%) of the sample was compared with a standard curve made from the corresponding readings of trolox solutions at different concentrations $(3-50 \mu \mathrm{g} / \mathrm{mL})$ and the results were expressed as $\mathrm{mg}$ of trolox equivalents/mg peptide.

\subsubsection{ORAC assay}

The fluorescence oxygen radical absorbance capacity (ORAC-FL) assay was based on that described by Contreras et al. [36]. The reaction was carried out at $40{ }^{\circ} \mathrm{C}$ in $75 \mathrm{mM}$ phosphate buffer (pH 7.4) and the final assay mixture $(200 \mu \mathrm{L})$ containing fluorescein $(70 \mathrm{nM})$, AAPH $(14 \mathrm{mM})$, and trolox $\left(9.98 \times 10^{-4}-7.99 \times 10^{-3} \mu \mathrm{mol} / \mathrm{mL}\right)$ or the peptide sample (five concentrations between 1 and $40 \mu \mathrm{g} / \mathrm{mL}$ ). The fluorescence was recorded during $137 \mathrm{~min}$ (104 cycles). A FLUOstar OPTIMA plate reader (BMG Labtech, Offenburg, Germany) with $485 \mathrm{~nm}$ excitation and $520 \mathrm{~nm}$ emission filters was used. The equipment was controlled by the FLUOstar Control software version (1.32 R2) for fluorescence measurements. Black polystyrene 96-well microplates (Nunc, Denmark) were used. AAPH and trolox solutions were prepared daily and fluorescein was diluted from a stock solution $(1.17 \mathrm{mM})$ in $75 \mathrm{mM}$ phosphate buffer $(\mathrm{pH} 7.4)$. All the reaction mixtures were prepared in duplicate and at least three independent measurements were performed for each sample. Final ORAC-FL values were expressed as $\mathrm{mg}$ of trolox equivalent/mg peptide.

\subsubsection{Nitric oxide scavenging assay}

Griess reagent was used to quantify nitrate and nitrite stable products formation after NO reaction with oxygen under aerobic conditions $[37,38]$. Sodium nitroprusside (SNP) was used, in aqueous solution at physiological $\mathrm{pH}$ (7.2), to produce NO. The SNP was prepared at $10 \mathrm{mM}$ with phosphate buffer saline (pH 7.4) and mixed with $0.5 \mathrm{~mL}$ of peptide solution. Peptides were both prepared in Milli-Q water at $0.5 \mathrm{mg} / \mathrm{mL}$ for antioxidin-RP1 and $2 \mathrm{mg} / \mathrm{mL}$ for antioxidin-I The mixture was then incubated at $25^{\circ} \mathrm{C}$ for $150 \mathrm{~min}$, then, $0.5 \mathrm{~mL}$ of Griess reagent (Sigma-Aldrich, Sintra, Portugal) was added and the mixture is incubated at $25^{\circ} \mathrm{C}$ for $30 \mathrm{~min}$. Absorbance was measured at $546 \mathrm{~nm}$. Final values were expressed as $\mathrm{mg}$ of trolox equivalent/mg peptide.

\subsection{Cytotoxicity assay}

Murine fibroblast cells (NIH-3T3) were acquired from cell bank of
Rio de Janeiro (Brazil) and were grown in Dulbecco's Modified Eagle's Medium (DMEM) (Life, EUA) completed with $10 \%$ of heat inactivated fetal bovine serum (Life, EUA) and 1\% of antibiotic solution (100 IU/ $\mathrm{mL}$ Penicillin - $100 \mu \mathrm{g} / \mathrm{mL}$ Streptomycin, Life, EUA) at $37^{\circ} \mathrm{C}$ and $5 \%$ $\mathrm{CO}_{2}$. For the viability assay, NIH-3T3 cells were seeded into 96-well culture plate at a density of $3 \times 10^{3}$ cells in DMEM culture medium overnight at $37{ }^{\circ} \mathrm{C}, 5 \% \mathrm{CO}_{2}$ in humid atmosphere. Then, the medium was changed and various concentrations of antioxidin-RP1 and antioxidin-I reconstituted in Milli-Q water were applied (400-12.5 $\mu \mathrm{g} / \mathrm{mL}$ ). Milli-Q water was used as control. The plates were incubated for $24 \mathrm{~h}$ at $37{ }^{\circ} \mathrm{C}, 5 \% \mathrm{CO}_{2}$ in humid atmosphere.

Cell viability assay was carried out using MTT (3-[4, 5-dimethylthiazol-2-yl]-2,5-diphenyltetrazolium bromide) dry reduction method. After $24 \mathrm{~h}$ of incubation, $15 \mu \mathrm{L}$ of the MTT solution $(5 \mathrm{mg} / \mathrm{mL}$ in phosphate buffer) was added to each well and the plate was incubated for $2 \mathrm{~h}$ at $37{ }^{\circ} \mathrm{C}$ and $5 \% \mathrm{CO}_{2}$ in humid atmosphere. The medium culture was discarded and $100 \mu \mathrm{L}$ of DMSO were added to each well. The absorbance was monitored using a spectrophotometer with a microplate reader at $595 \mathrm{~nm}$ (Molecular Devices, EUA). The morphological characterization of fibroblast cells was performed with an inverted fluorescence microscope EVOS ${ }^{\oplus}$ FL Auto (Life Technology, Waltham, $\mathrm{MA}$ ), with magnification of $10 \mathrm{X}$ and the images were obtained in phase contrast mode using EVOS ${ }^{\circ}$ FL Auto Software v1.7 (REV 32044) (Thermofisher Scientific).

\subsection{Glutathione redox balance experiment}

$\mathrm{NIH}-3 \mathrm{~T} 3$ cells were seeded in triplicate into 12 -well culture plate at a density of $5 \times 10^{4}$ cells in DMEM culture medium overnight at $37^{\circ} \mathrm{C}$, $5 \% \mathrm{CO}_{2}$ in humid atmosphere. Then, $400 \mu \mathrm{g} / \mathrm{mL}$ of antioxidin-I reconstituted in Milli-Q water were applied and the plates were incubated at $37{ }^{\circ} \mathrm{C}, 5 \% \mathrm{CO}_{2}$ in humid atmosphere. After $18 \mathrm{~h}$ of incubation, $20 \mu \mathrm{M}$ of menadione (diluted in ethanol) were added to cells previously exposed or not to antioxidin-I. The plates were incubated for $6 \mathrm{~h}$ at $37^{\circ} \mathrm{C}$, $5 \% \mathrm{CO}_{2}$ in humid atmosphere. Milli-Q water and ethanol were used as controls.

For the measurement of glutathione, in its reduced and disulfide forms, the samples were prepared according to the protocol proposed by Rahman and coworkers [39]. Cells were washed twice with cold, $\mathrm{Ca}^{2+} / \mathrm{Mg}^{2+}$ free PBS and $500 \mu \mathrm{L}$ of trypsin-EDTA were added to each well at room temperature $\left(22-25^{\circ} \mathrm{C}\right)$ for $5 \mathrm{~min}$. One milliliter of cold DMEM culture medium was added to neutralize the trypsin-EDTA effect. The cell suspension was centrifuged at $1000 \times g$ for 5 min at $4{ }^{\circ} \mathrm{C}$. The supernatant was discarded and the cell pellet was frozen in liquid nitrogen and stored at $-80{ }^{\circ} \mathrm{C}$ until analysis. Cells were suspended in $10 \%$ trichloroacetic acid and lysed by three cycles of 1 min ultrasonic ice-cold bath and $10 \mathrm{~s}$ vortex. To safely achieve cell lysis the extract was frozen at $-80^{\circ} \mathrm{C}$ and thawed in ice. The cell extract was centrifuged at $10,000 \times g$ for $10 \mathrm{~min}$ at $4{ }^{\circ} \mathrm{C}$. One aliquot of the supernatant was used to measure total glutathione and other aliquot for disulfide glutathione using the enzymatic recycling method [39].

\subsection{Hypoxia-induced ROS production in living microglia}

\subsubsection{Microglial cell line}

The human microglial cell line CHME3 was obtained from primary cultures of human embryonic microglial cells by transfection with a plasmid encoding for the large T antigen of SV40 [40]. These cells were previously used in microglial studies demonstrating similar behavior relative to primary cultures [40]. CHME3 microglia were cultivated as previously described [41]. In brief, cells were cultured in DMEM GlutaMAX ${ }^{\mathrm{TM}}-\mathrm{I}, 100 \mathrm{U} / \mathrm{mL}$ penicillin, and $100 \mu \mathrm{g} / \mathrm{mL}$ streptomycin supplemented with $10 \%$ FBS. Cells were kept at $37{ }^{\circ} \mathrm{C}, 95 \%$ air, and $5 \% \mathrm{CO}_{2}$ in a humidified incubator. Cultures were plated on plastic-bottom culture dishes ( $\mu$-Dish $35 \mathrm{~mm}$, iBidi) for live imaging experiments. For the assays, microglia were transiently transfected with the HyperRed ROS 
biosensor [42] using Jetprime (Polyplus), according to manufacturer's instructions.

\subsubsection{Microscope set-up}

Experiments were performed on a fully-motorized DMI6000B microscope (Leica Microsystems) equipped with filter cubes for cyan fluorescent protein (CFP) (BP 427/10) and yellow fluorescent protein (YFP) (BP 504/12) working with specific dichroic (CG1 440/520) and a separate filter cube for monomeric red fluorescent protein (mRFP) (Ex. BP580/20; DM 595; Em. 630/55) mounted into a microscope filter carrousel (Leica fast filter wheels). The excitation light source was a mercury metal halide bulb integrated with the EL6000 light attenuator. Cells were observed with a PlanApo 63X 1.3NA glycerol immersion objective with correction ring. An ORCA-Flash4.0 V2 Digital CMOS camera (Hamamatsu) coupled to the microscope through a $1.3 \mathrm{x}$ cmount adapter was used to acquire images. The LAS X software (Leica Microsystems) controlled all microscope parameters. Shading illumination was online-corrected for using a shading correction routine implemented for the LAS X software. At each time point, CFP/CFP (donor) and CFP/YFP (FRET) images for the HSP FRET sensor or mRFP/ mRFP for HyperRed images were sequentially acquired using $2 \times 2$ camera binning with an exposure time of $800 \mathrm{~ms}$. A digital small-stage incubator (iBidi) was used real-time monitoring of environmental conditions (temperature, gas mixture and humidity) and to maintain the cells under normoxia $\left(20 \% \mathrm{O}_{2} ; 5 \% \mathrm{CO}_{2} ; 89-92 \%\right.$ humidity) or subject them to hypoxia $\left(2 \% \mathrm{O}_{2} ; 5 \% \mathrm{CO}_{2} ; 89-92 \%\right.$ humidity). Transfected cells expressing HyperRed were randomly selected from the dishes and imaged.

\subsubsection{Biosensor quantification}

Time-lapse images were exported as 16-bit tiff files and processed in the FIJI software as before [41,43-45]. In brief, background was dynamically subtracted from time-lapses using the rollerball algorithm. Cells from time-lapses in the Donor to FRET or mRFP channel were individually segmented and thresholded using the Phansalkar local threshold algorithm for the generation of black/white binary masks. Afterwards, cells in the original time-lapse images were multiplied by their corresponding binary masks and new masked images were generated in 32-bit floating point tiff images. Masked time-lapses images were then registered using the StackReg plugin in FIJI. Photobleaching on the time-lapses was corrected by a bi-exponential fitting curve using a custom-made FIJI routine. Whole cell HSP Donor/FRET ratio or HyperRed mean gray intensity values throughout the time-lapses were retrieved and plotted.

\subsection{Statistical Analysis}

Values were expressed as mean \pm standard error of the mean (SEM). The differences in the effects of compound treatment compared with control values were analyzed by ANOVA and Tukey post-hoc test using the software Prism 5 (EUA). The significant level was set to $\mathrm{P}<0.05$.

\section{Results and discussion}

\subsection{Purification and structural characterization of antioxidin}

The cutaneous secretion of $P$. nattereri was fractionated by C18 RTHPLC and it resulted in a complex chromatographic profile (Fig. 1). Aliquots of the 52 chromatogram peaks were analyzed by MALDI-TOF/ MS, subsequently selected ions of interest were fragmented for de novo sequencing. Antioxidin-I, a peptide with a molecular weight $[\mathrm{M}+\mathrm{H}]^{+}$ $=1543.69 \mathrm{Da}$ and a preliminary amino acid sequence TWYFITPYIPDK with L/I and K/Q ambiguities and a R-COOH C-terminal was identified (Fig. S1). Peaks with similar retention times, attributed to antioxidin-I, were also detected in the skin secretion of other tropical frogs. In

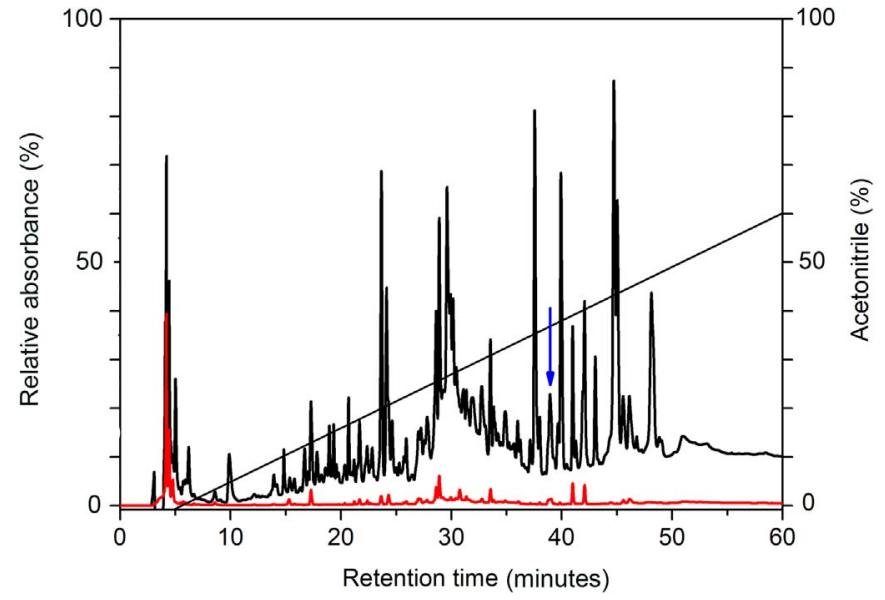

Fig. 1. Reverse phase HPLC chromatogram of the crude extract from P. nattereri skin secretion. The absorbance was monitored at 216 (black) and $280 \mathrm{~nm}$ (red line) in arbitrary units (mAU). Fraction containing antioxidin-I is shown with blue arrow. (For interpretation of the references to color in this figure legend, the reader is referred to the web version of this article).

parallel, total RNA was extracted from the dorsal skin of $P$. nattereri, $P$. distincta, $P$. rohdei and $P$. tarsius and reverse-transcribed to cDNA using specific primers (Table S1), cloned and sequenced. The sequence of antioxidin-I precursor was obtained and allowed the solution of $\mathrm{L} / \mathrm{I}$ and $\mathrm{K} / \mathrm{Q}$ ambiguities that remained after de novo peptide sequencing (Fig. 2). Similar to some peptides with no antimicrobial activity from frog skin secretions $[6,46]$, the structure of antioxidin-I precursor contains a conserved signal peptide, an acid piece and an active peptide region bearing endopeptidase cleavage sites, commonly described to antimicrobial peptide precursors [47]. These data highlight a conserved basic design to all, or almost all, active peptide's precursors produced by granular glands, showing that its structure is not exclusive for antimicrobial peptides. Unexpectedly, cDNA sequencing demonstrated that the four studied frog species express the same mRNA for antioxidin-I with minor polymorphism between nucleotide sequences that do not affect the amino acid sequence (Fig. 2). Even though the arsenal of bioactive peptides in the skin of each amphibian species is generally different, the identification of the same bioactive peptide in more than one amphibian species was previously reported. Namely, the case of the antimicrobial peptide dermaseptin 01 [48] originally identified in $P$. oreades, that was afterwards also identified in other three species in same genus: $P$. azurea, $P$. nordestina, and $P$. hypochondrialis $[49,50]$. In this work, we report the peptide antioxidin-I that was present in three genera of tropical amphibians. These observations evidence that antioxidin-I potentially performs an important and an efficient physiological role contributing to maintenance of frog's homeostasis.

The usual nomenclature for new AOPs from frog's skin secretions uses the term "antioxidin" followed by first letter of the two names comprising the specie name (genus plus specific epitope). For example, Song et al. [51] described an AOP isolated from Pelophylax nigromaculatus named as antioxidin-PN. Other examples are antioxidin$\mathrm{RL}$ and antioxidin-RP from Odorrana livida and Rana pleuraden, respectively $[9,12]$. AOPs that also have antimicrobial activities are conventionally named as the antimicrobial peptides, e.g. daiyunin- 1 and taipehensin-1 from Amolops daiyunensis and Hylarana taipehensis, respectively $[10,11]$. The exceptions are AOPs fragilin-A1, fragilin-B1 and odorranain-Q-Lf isolated from Limnonectes fragilis that do not have significant antimicrobial activities [52]. Here, we named a new AOP as antioxidin-I because: 1) the use of first letter of genus and specific epitope may cause mistakes (antioxidin-PN can be related to e.g. Pelophylax nigromaculatus or Physalaemus nattereri); 2) it is present in four different frog species comprising three genera and 3) because antioxidin-I do not have antibacterial activities. As the number of AOP 


\section{P. distincta \\ $P$. nattereri \\ P. rohdei \\ P. tarsius}

\section{P. distincta \\ $P$. nattereri \\ P. rohdei \\ $P$. tarsius}

\section{$P$. distincta \\ $P$. nattereri \\ P. rohdei \\ $P$. tarsius \\ P. distincta \\ $P$. nattereri \\ P. rohdei \\ P. tarsius}

\section{P. distincta \\ $P$. nattereri \\ P. rohdei \\ P. tarsius}

\section{P. distincta \\ $P$. nattereri \\ P. rohdei \\ P. tarsius}

$\begin{array}{lllllllllllllllll}M & A & F & L & K & K & S & L & F & L & V & L & F & L & G & L & V\end{array}$ ATGGCTTTCCTGAAGAAATCTCTTTTCCTTGTACTATTCCTTGGATTGGT ATGGCTTTCCTGAAGAAATCTCTTTTCCTTGTACTATTCCTTGGATTGGT ATGGCTTTCCTGAAGAAATCTCTTTTCCTTGTACTATTCCTTGGATTGGT ATGGCTTTCCTGAAGAAATCTCTTTTCCTTGTACTATTCCTTGGATTGGT

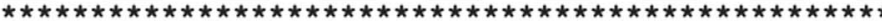

$S \quad I \quad S \quad V \quad C \quad E \quad D \quad E \quad E \quad E \quad K \quad R \quad G \quad E \quad D \quad E$ TTCCCTTTCCGTCTGTGAGGATGAAGAAGAGAAAAGAGGAGAAGATGAAG TTCCCTTTCCGTCTGTGAGGATGAAGAAGAGAAAAGAGGAGAAGATGAAG TTCCCTTTCCGTCTGTGAGGATGAAGAAGAGAAAAGAGGAGAAGATGAAG TTCCCTTTCCGTCTGTGAGGATGAAGAAGAGAAAAGAGGAGAAGATGAAG

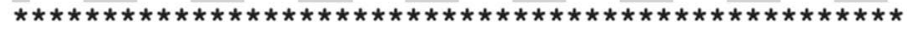

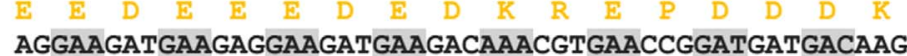
AGGAAGATGAAGAGGAAGATGAAGACAAACGTGAACCGGATGATGACAAG AGGAAGATGAAGAGGAAGATGAAGACAAACGTGAACCGGATGATGACAAG AGGAAGATGAAGAGGAAGATGAAGACAAACGTGAACCGGACGATGACAAG

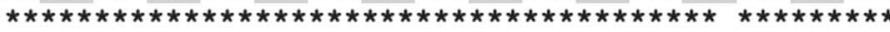
$\begin{array}{llllllllllllllllll}D & R & R & T & W & Y & F & I & T & P & Y & I & P & D & K & \bullet\end{array}$ GATAGGCGTACATGGTACTTCATAACTCCTTATATTCCAGATAAATAAAA GATAGGCGTACATGGTACTTCATAACTCCTTATATTCCAGATAAATAAAA GATAGGCGTACATGGTACTTCATAACTCCTTATATTCCAGATAAATAAAA GATAGGCGTACATGGTACTTCATAACTCCTTATATTCCAGATAAATAAAA

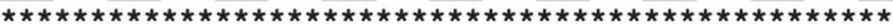

TCTGGTGACGACATCCGACAGCAGAAAGCATAATTATTCTTAGTTATGCC TCTGGTGACGACATCCGACAGCAGAAAGCATAATTATTCTTAGTTATGCC TCTGGTGACGACATCCGACAGCAGAAAGCATAATTATTCTTAGTTATGCC TCTGGTGACGACATCCGACAGCAGAAAGCATAATTATTCTTAGTTATGCC

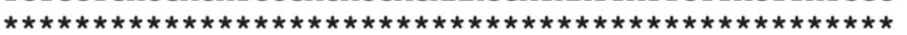

CTAATATAATAAAGCCTATGTAACTGAAAAGAAAAAAAAAAAAAAAAAAA CTAATATAATAAAGCCTATGTAACTGATAAAAAAAAAAAAAAAAAAAAAA CTAATATAATAAAGCCTATGTGACTAAAAAAAAAAAAAAAAAAAAAAAAA CTAATATAATAAAGCCTATGTAACTGAAAGAAAAAAAAAAAAAAAAAAAA

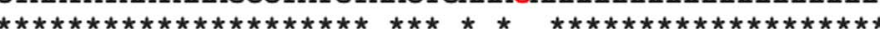

Fig. 2. cDNA sequence and predicted amino acid sequences of antioxidin-I from Phyllomedusa distincta, P. rohdei, P. tarsius and Physalaemus nattereri. Signal peptide, acid pierce and mature peptide are in green, orange and blue, respectively. Nucleotide polymorphisms are highlighted in red. The black dot indicates stop codon. The asterisks indicate homology. (For interpretation of the references to color in this figure legend, the reader is referred to the web version of this article). isolated from frog's skin secretion can increase yet, we suggest that a new nomenclature for this class of molecules must be proposed.

Antioxidin-I has an unusual sequence unrelated to previously known families of antioxidant and/or antimicrobial peptides (AMPs), presenting less than $33.3 \%$ of sequence similarity (Table 1 ) with the sequences of similar described peptides (tigeninin-1 and temporin-SN4 and -SN2). Analysis in silico showed a neutral net charged molecule, with no hydrophobic residues on the same surface evidenced by HeliQuest (Fig. 4C and D) and reduced sequence similarity in regard to other characterized peptides (Table 1). As predicted by ADP database software, antioxidint-I had poor antimicrobial activity (see Antimicrobial activity section and Table 2). Such observation corroborates the empirical results obtained by $\mathrm{CD}$ analysis that demonstrated the lack of the typical alpha-helix secondary structure described for AMPs, even at higher TFE concentrations. Instead, a random structure is

Table 1

Primary amino acid sequence of antioxidant peptides, similarity with other peptides sequences and additional physicochemical properties for (antioxidin-I).

\begin{tabular}{llll}
\hline Peptide & Sequence & Similarity $^{\mathrm{a}}$ (\%) & Reference \\
\hline Antioxidin- $^{\mathrm{b}}$ & TWYFIT- -PYIP-DK & & Present study \\
Tigerinin-1 $^{\text {Temporin-SN4 }}$ & -- -FCTMIP-IPRCY & 33.30 & Sai et al., 2001 \\
Te-FITGLISGLMKAL & 31.25 & Yang et al., 2013 \\
Temporin-SN2 $^{\text {c }}$ & -- -FITGLIGGLMKAL & 31.25 & Yang et al., 2013 \\
Antioxidin-RP1 $^{\mathrm{c}}$ & AMRLTYNKPCLYGT & & Yang et al., 2009 \\
\hline
\end{tabular}

${ }^{\text {a }}$ Percentage of sequence similarity with antioxidin-I.

${ }^{b}$ Molar absorptivity coefficient a $280 \mathrm{~nm}: 8250 \mathrm{M}^{-1} \mathrm{~cm}^{-1}$; iso-electric point: $\mathrm{pH} 6.3$; net charge at $\mathrm{pH}$ 7.0: 0 ; Wimley-White whole-residue hydrophobicity: $-2.08 \mathrm{kcal} / \mathrm{mol}$; protein binding potential (Boman index) $0.37 \mathrm{kcal} / \mathrm{mol}$ (Rey, 2009).

${ }^{\mathrm{c}}$ Antioxidin-RP1 was used as a reference of antioxidant peptide (positive control).
Table 2

Antimicrobial activity assessment by minimum inhibitory concentration values $(\mu \mathrm{g} / \mathrm{mL})$ of antioxidin-I and antioxidin-RP1 against E. coli, P. aeruginosa, S. aureus and E. faecalis.

\begin{tabular}{lllll}
\hline Peptide & \multicolumn{4}{l}{ Bacterial strain } \\
\cline { 2 - 5 } & $\begin{array}{l}\text { E. coli } \\
\text { ATCC 25922 }\end{array}$ & $\begin{array}{l}\text { P. aeruginosa } \\
\text { ATCC 27853 }\end{array}$ & $\begin{array}{l}\text { S. aureus } \\
\text { ATCC 25923 }\end{array}$ & $\begin{array}{l}\text { E. faecalis } \\
\text { ATCC 29212 }\end{array}$ \\
\hline Antioxidin-I & $>1024$ & $>1024$ & $>1024$ & $256^{\text {a }}$ \\
Antioxidin-RP1 & $>1024$ & $>1024$ & $>1024$ & $>1024$ \\
\hline
\end{tabular}

${ }^{\mathrm{a}}$ The minimum bactericidal concentration was $>1024 \mu \mathrm{g} / \mathrm{mL}$.

evidenced for antioxidin-I regardless of solvent polarity (Fig. 4A and B). $\mathrm{CD}$ results were consistent with theoretical 3D structure studies performed in silico using the internet resources PEP-FOLD, where it was observed that the peptide is folded onto itself. The same was observed for the antioxidin-RP1 structure (Fig. 4E and F). These open structures could be related to the access to electron transfer and, thus, with a potential antioxidant activity. Antioxidin-RP1 was chosen as a comparative reference peptide because of its reportedly high antioxidant activity [9]. Accordingly, we performed four different radical scavenging assays with successful results.

\subsection{Spatial expression of antioxidin-I in P. nattereri skin}

The total RNA samples extracted from inguinal macroglands and dorsal skin tissue of $P$. nattereri were used for cDNA synthesis and then used in qPCR assays. The expression level of the antioxidin-I was higher in dorsal skin tissue than in inguinal macroglands (Fig. 3), suggesting that this peptide may have an intrinsic role in the skin of $P$. nattereri. Barbosa et al. [6] showed that for $P$. nattereri, bradykinin gene 


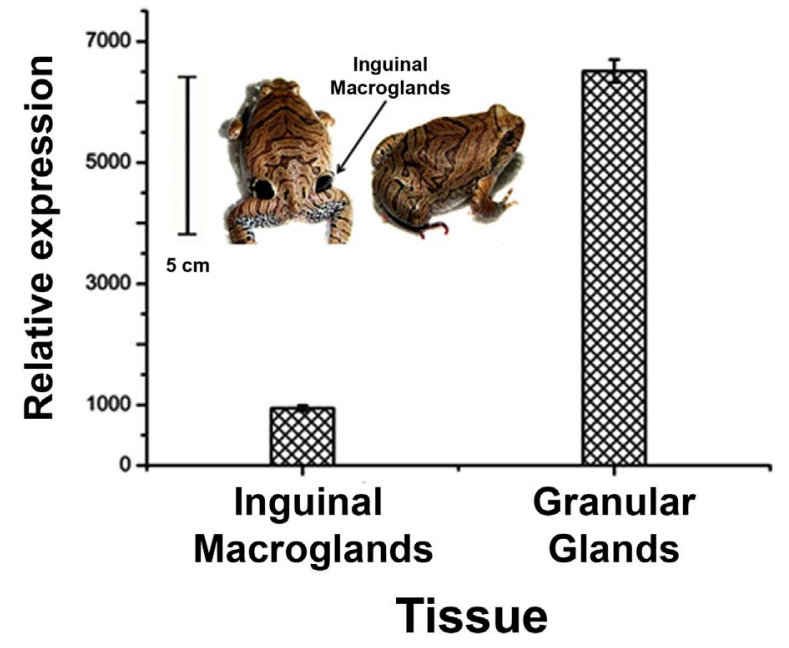

Fig. 3. Spatial expression of antioxidin-I precursor in the skin tissue of $P$. nattereri. The relative expression was performed by real-time qPCR from two distinct skin regions: inguinal macroglands and granular glands (spread on the dorsal surface). (A) Adult specimens of $P$. nattereri, with indication of inguinal macroglands. (B) Relative expression test of antioxidin-I precursor by qPCR comparing inguinal macroglands and granular glands.

transcription and its peptide product were detected mainly in inguinal macroglands. In this case, bradykinins are produced (and stocked) mainly by inguinal macroglands waiting for a specific event such as an attack of a predator. On the other hand, antioxidin-I has a widespread localization. This is consistent with the hypothetical physiological role proposed for these peptides, which would be the scavenging of reactive species overproduced as a result of oxygen availability transitions and UV radiation exposure (Fig. 4).

\subsection{Antimicrobial activity}

The antibacterial activity of antioxidin-I and antioxidin-RP1 (used as a reference) was evaluated against two Gram-negative (Escherichia coli ATCC 25922 and Pseudomonas aeruginosa ATCC 27853) and two Gram-positive (Staphylococcus aureus ATCC 25923 and Enterococcus faecalis ATCC 29212) strains. As predicted by the APD database tool, both antioxidin-I and antioxidin-RP1 had no relevant inhibitory activity against the strains tested (Table 2). Antioxidin-I presented a MIC value higher than $1024 \mu \mathrm{g} / \mathrm{mL}$ against the Gram-negatives and $S$. aureus. Antioxidin-I had a lower MIC $(256 \mu \mathrm{g} / \mathrm{mL})$ against $E$. faecalis compared with antioxidin-RP1. The value of $256 \mu \mathrm{g} / \mathrm{mL}$ is still rather high to foresee antibacterial potential.

\subsection{Antioxidant activity theoretical prediction}

The prediction indicated that antioxidin-I has 149 atoms and the molecular formula is $\mathrm{C}_{78} \mathrm{H}_{38} \mathrm{~N}_{14} \mathrm{O}_{19}$. Crystallographic data confirmed the distances of both conventional and unconventional hydrogen bonds showing no discrepancy in the binding values. The energies obtained for the neutral and the negative peptide structure were -5189.08234109 au and -5188.58209572 au respectively. Taking into account the contribution of each $\mathrm{H}$ atom $(-0.56119365 \mathrm{au})$ with the molecule stabilizing energy and disregarding the contributions provided by hydrogen bonds, radicals and ions, a comparison of the structures stabilities was performed (Table S3) (Oliveira et al., 2016). The comparison shows that the negative peptide is more stable than the neutral one due to an existing hydrogen connection in the structure. Both structures show a hydrogen bond closing the structure (Fig. S1). The hydrogen bond responsible for that closure is stronger in the negative peptide (Fig. S1B) than in the neutral peptide (Fig. S1A) explaining the greater stability of the structure (Fig. 5).

\subsection{In vitro radical scavenging}

Peptides have been shown to act as radical scavengers and such activity is related to their amino acid composition, sequence, structure, and hydrophobicity. Aromatic residues (Tyr, Trp, and Phe) are able to donate electrons while keeping their own stability via resonance structure [53]. Moreover, His-containing peptides have been shown to be good radical scavengers [54]. The content of hydrophobic amino acids is associated with enhanced antioxidative properties, especially from naturally occurring peptides [55]. In addition, high acidic amino acid content and their amides may partly be responsible for the strong antioxidant effects observed due to the presence of excess electrons [56]. Antioxidin-I and antioxidin-RP1 ability to scavenge radicals in vitro was evaluated by four different systems (ABTS, DPPH, ORAC and NO) (Table 3). Antioxidin-RP1 had higher activity than antioxidin-I in ABTS, DPPH and NO assays. Antioxidin-I was found to cause the highest inhibition of fluorescein decay, resulting in the highest ORAC value $4.088 \mathrm{mg}$ Trolox/mg of peptide. Antioxidin-I had 136\% more antioxidant capacity than antioxidin-RP1 in the ORAC method.

The ORAC assay measures the inhibition of peroxyl radical-induced oxidations and thus reflects classical radical chain breaking by hydrogen transfer. Antioxidant peptides containing aromatic amino acid residues (Trp and Tyr) in the sequence have strong radical scavenging activities due to the labile hydrogen atom. Tyr acts as hydrogen donor by containing hydroxyl, which also exists in polyphenol and synthetic antioxidants. Most in vitro assays use a stable radical chemically generated that does not occur in vivo (e.g. ABTS, DPPH); therefore, it may be more biologically relevant to use radical molecules that are similar to those occurring in vivo. This is the case of nitric oxide and the peroxyl radical generated in the ORAC assay [57], which is the method of choice in the food and pharmaceutical industries [58]. In the case of antioxidin-RL, the Cys10 is the determinant residue in the radical scavenging activity of the peptide extracted from Odorrana livida skin [12]. Many antioxidant peptides with variable structures were isolated from the skin secretions of $R$. pleuraden, including the antioxidin-RP1, which had the highest performance in several radical scavenging activity in vitro. Such activity was attributed to the presence of critical residues of methionine, cysteine, tyrosine and proline [9]. Regardless, such in vitro assays are highly limited and the interpretation of the potential activity in vivo should be corroborated by other methods.

\subsection{Antioxidin effects on fibroblast viability and redox balance}

The cytotoxicity of the peptides antioxidin-I and antioxidin-RP1 was analyzed by colorimetric MTT assay. Both peptides demonstrated low cytotoxic activity when exposed to murine fibroblasts cells NIH3T3 at concentrations from 12.5 to $400 \mu \mathrm{g} / \mathrm{mL}$ for $24 \mathrm{~h}$. The highest decrease of cell viability was about $20 \%$ and was observed at $400 \mu \mathrm{g} / \mathrm{mL}$ of antioxidin-RP1 (Fig. 6). The evaluation of the cytotoxicity of peptides isolated from amphibian skin in normal cells is relevant and important to determine the biocompatibility. Brand and co-workers [50] demonstrated that peptides isolated from the skin secretion of Phyllomedusa nordestina had no toxicity against mouse peritoneal macrophages. Additionally, low hemolytic and cytotoxic activity were detected in human erythrocytes and in the murine fibroblasts cell line NIH3T3, after $60 \mathrm{~h}$ exposure to peptides isolated from the skin secretion of the frog Leptodactylus pustulatus [59].

Glutathione is the most abundant non-protein thiol in eukaryotic cells. This tripeptide, in addition to thioredoxin, acts as a redox buffer, affecting many redox sensitive pathways. In that regard, the ratio between disulfide (GSSG) and total glutathione (GSH-eq) levels is a good indicator of the cellular redox balance [60], although one cannot derive the actual redox potential solely based on glutathione levels $[61,62]$. We tested the ability of antioxidin-I to avoid redox metabolism disruption in oxidatively challenged NIH3T3 cells. Menadione treatment resulted in a more oxidized state in fibroblasts, as indicated by the 8- 

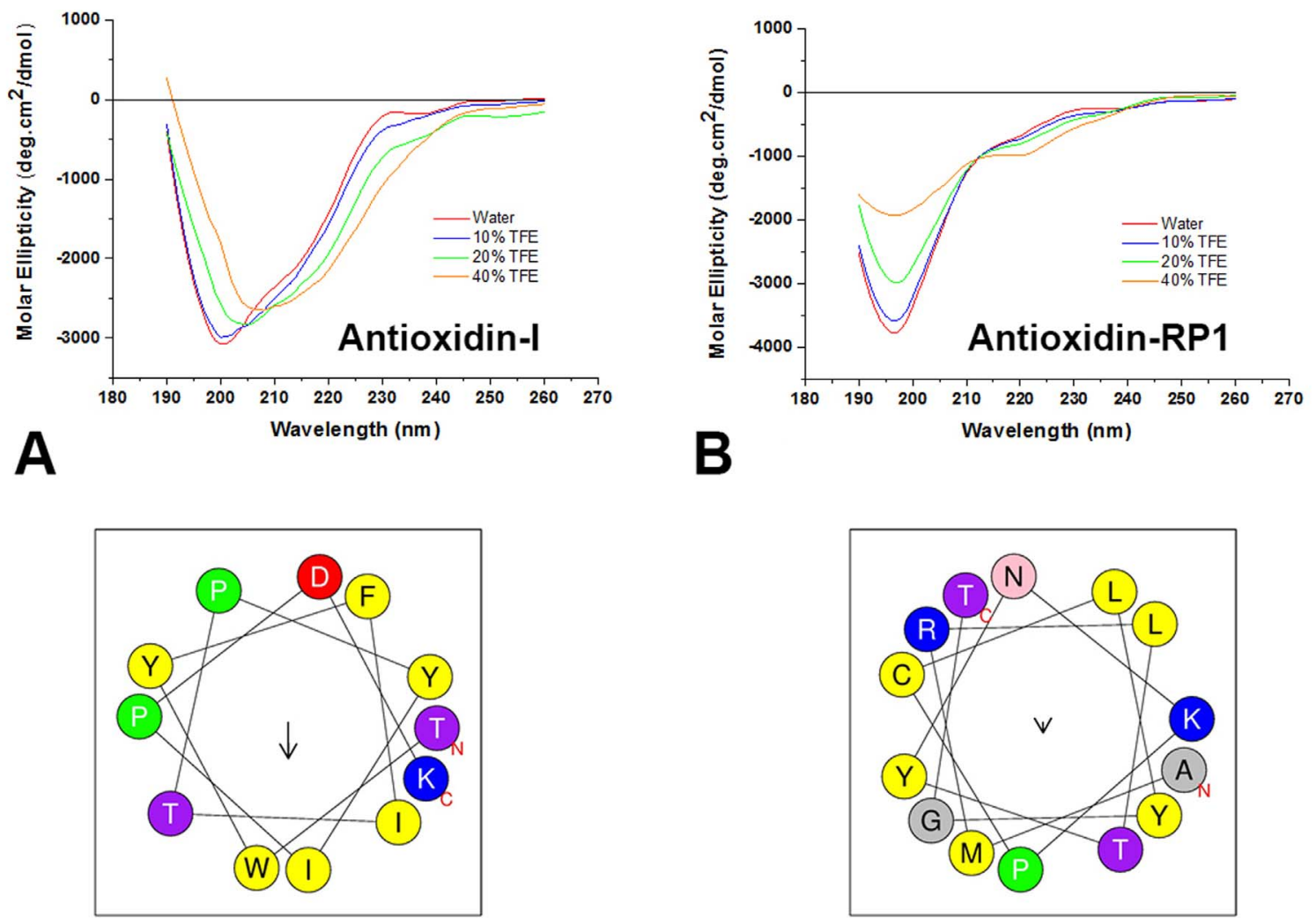

Net charge: 0

Hydrophobicity $(\mathrm{H})=0.813$

C Hydrophobic momento $(\mu \mathrm{H})=0.242$

\section{Antioxidin-I TWYFITPYIPDK}
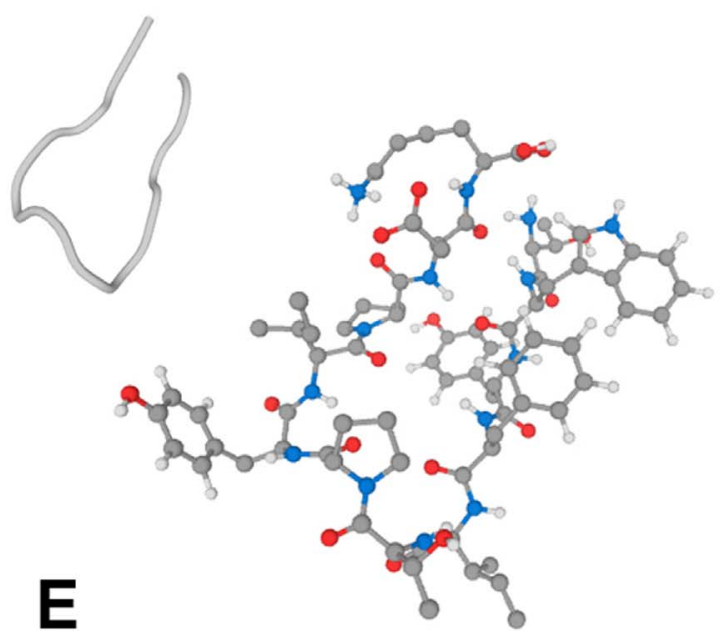

E

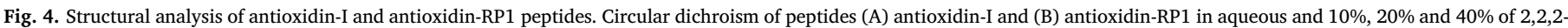

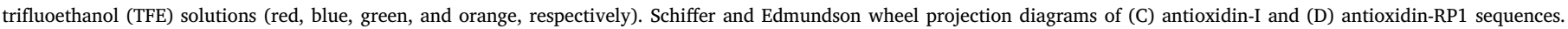

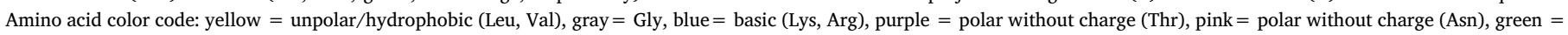

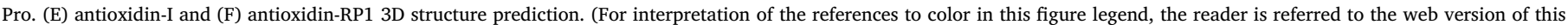
article).

fold increase in GSSG/GSH-eq ratio (Fig. 7). When cells were pre-incubated with antioxidin-I, the menadione treatment was unable to cause significant redox imbalance in fibroblasts. Importantly, cell treatment with antioxidin-I without any other stimulation had no effect on redox balance.

\subsection{Antioxidin effect on hypoxia-induced ROS generation by microglia}

Finally, we assessed the antioxidant capacity of antioxidin-I in another cell system. For this, we used microglia, the myeloid resident cells of the central nervous system (CNS). Microglia respond to tissue damage and infection by producing and releasing reactive oxygen species (ROS) to the surrounding CNS milieu $[63,64]$. Therefore, microglia 

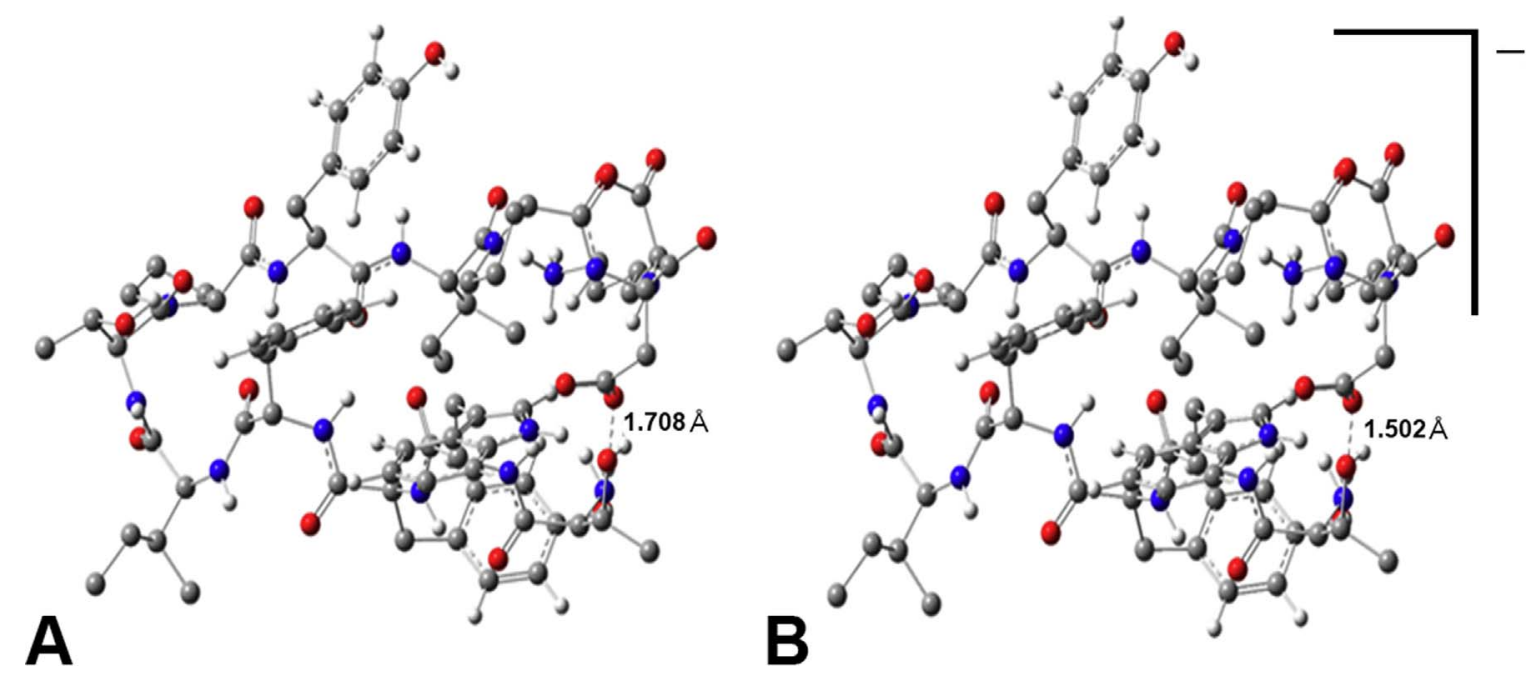

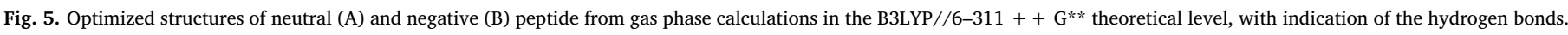

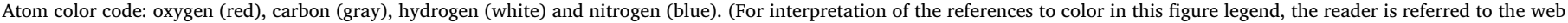
version of this article).

Table 3

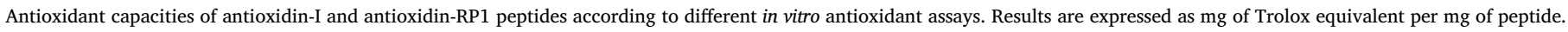

\begin{tabular}{|c|c|c|c|c|}
\hline \multirow[t]{2}{*}{ Peptide } & \multicolumn{4}{|c|}{ Antioxidant assay } \\
\hline & ABTS & DPPH & ORAC & No \\
\hline Antioxidin-I & $0.010 \pm 0.009$ & $0.0019 \pm 0.0004$ & $4.088 \pm 0.214$ & $0.019 \pm 0.004$ \\
\hline Antioxidin-RP1 & $0.300 \pm 0.002$ & $0.053 \pm 0.003$ & $1.729 \pm 0.151$ & $0.115 \pm 0.028$ \\
\hline
\end{tabular}

ABTS (2,2'-azino-bis(3-ethylbenzothiazoline-6-sulphonic acid).

DPPH (2,2-diphenyl-1-picrylhydrazyl).

ORAC (Oxygen Radical Absorbance Capacity).

NO (Nitric Oxide).

constitute an adequate cellular model to test whether antioxidin-I displays any antioxidant capacity in mammalian cells. Human microglial cells were subjected to hypoxia, a condition known to induce ROS production [65], either in the presence or in the absence of antioxidin-I. We then monitored ROS generation in living microglia by time-lapse video microscopy using the HyperRed ROS biosensor [42]. Hypoxia induced a clear production of ROS by microglia (Fig. 8, upper panels and black line on the graph), however, pre-incubation with $100 \mu \mathrm{M}$ antioxidin-I significantly prevented the hypoxia-induced ROS generation by living microglia (Fig. 8, bottom panels and red line on the graph). Because such result could be, at least partially, an effect of $\mathrm{pH}$ perturbations, we further confirmed the specificity of antioxidin-I-dependent inhibition of ROS production using a FRET biosensor. This probe is less sensitive to intracellular $\mathrm{pH}$ fluctuations than HyperRed. As expected, experiments with the HSP FRET sensor in living microglia confirmed that pre-incubation with $100 \mu \mathrm{M}$ antioxidin-I abrogated the generation of ROS triggered by hypoxia (Fig. 8C).

Supplementary material related to this article can be found online at http://dx.doi.org/10.1016/j.freeradbiomed.2017.11.001.

Stroke is responsible for $10 \%$ of all deaths worldwide [66]. It is estimated that around $25 \%$ of stroke patients will not survive beyond the first month and of those who survive past 6 months, roughly $30 \%$ will require lasting institutional care [66]. On top of that, the lack of effective treatments for stroke puts great pressure for the development of new therapeutics, such as the use of neuroprotective molecules, to attenuate or halt brain damage after stroke [67]. During stroke, there is a decreased delivery of oxygen to the insulted brain tissue, massive production of ROS to the surrounding brain milieu and neuronal damage. Microglia become activated by hypoxia $[63,64]$ and start producing free radicals in the core of the lesion, which largely contributes for exacerbating neurotoxicity after stroke. Abrogation of ROS production by microglia is therefore claimed to be neuroprotective $[63,64]$. Because in the presence of antioxidin-I the generation of ROS by microglia subjected to hypoxia was impaired, our data suggest a potential neuroprotective effect for antioxidin-I. Whether antioxidin-I also displays antioxidant properties in other cells from the brain parenchyma, like astrocytes or neurons, and the molecular targets affected by antioxidin-I in microglia warrants further investigation.

\section{Final statements}

Herein, antioxidin-I, an antioxidant peptide, was found to be expressed in the skin of four frog species from three distinct genera. This peptide had higher antioxidant capacity than antioxidin-RP1 as measured by the ORAC assay, probably due to the presence of Trp aromatic residues. On the other hand, antioxidin-I had a lower capacity to scavenge the free radicals of ABTS, DPPH and NO than antioxidin-RP1, probably due to the absence of Cys residues $[9,12]$. Antioxidin-I presented antioxidant activity in cell culture assays. It was able to reduce both menadione-induced redox imbalance in fibroblasts and ROS levels in hypoxia-challenged microglia. Such observations highlight the current view that exogenous antioxidants in biological systems may act rather as signals instead of free radical scavengers [68]. Antioxidin-I presented poor radical scavenging activity in three of the four in vitro assays. In cell culture assay, however, it was able to minimize or avoid redox imbalance in oxidatively challenged cells. The cellular mechanisms that support such effect remain to be elucidated.

The potential health benefits of peptides derived from natural sources are increasingly attracting interest. They combine low-molecular-weight, high activity, easy absorption, and much reduced 

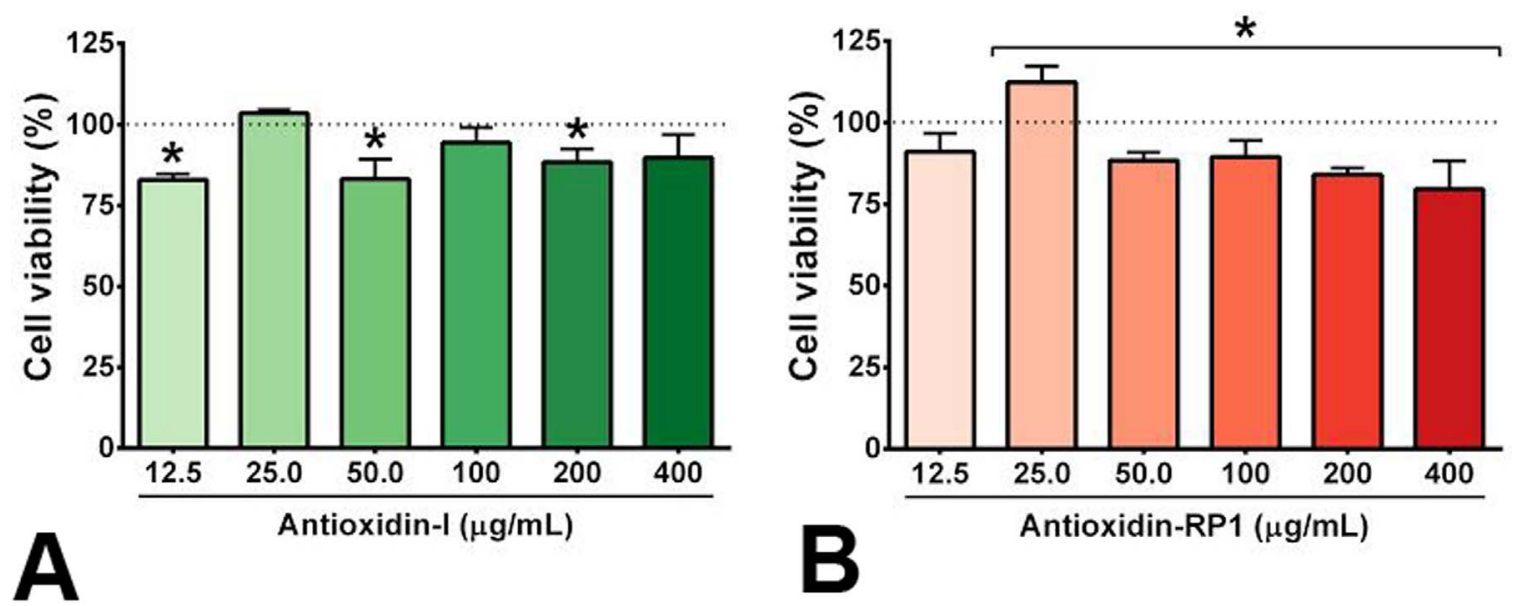

\section{NIH 3 T3 Cells}
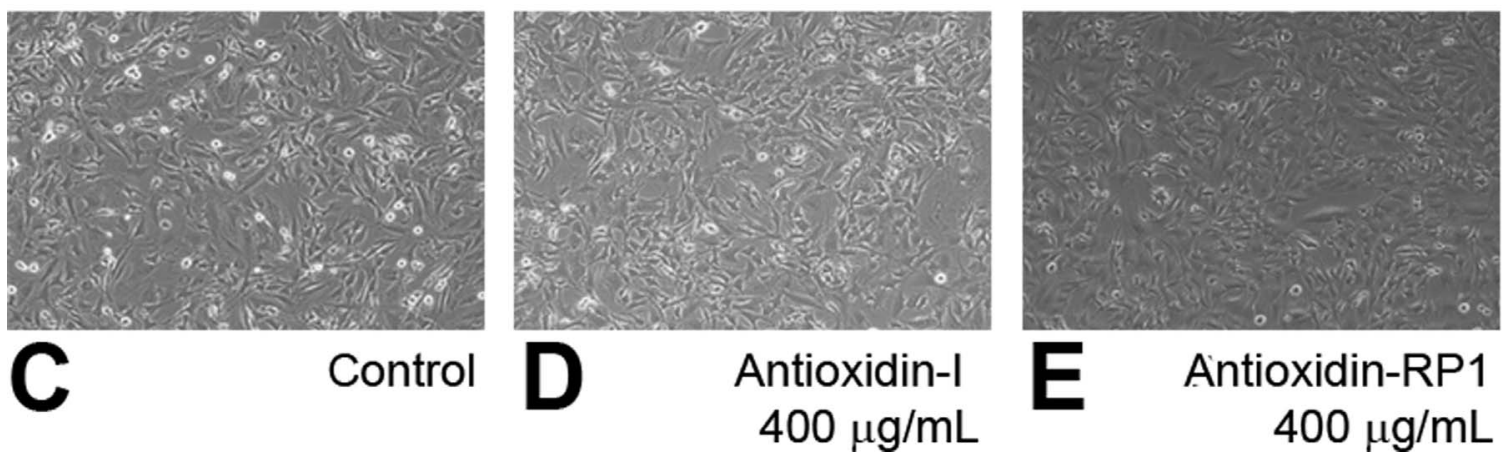

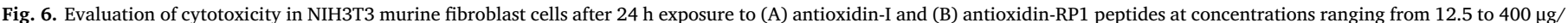

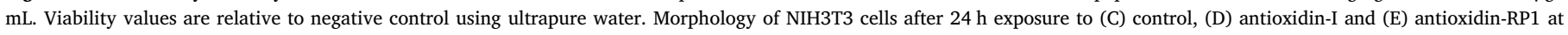
$400 \mu \mathrm{g} / \mathrm{mL}$. Asterisks denote statistically significant differences against negative control $(\mathrm{P}<0.05)$.

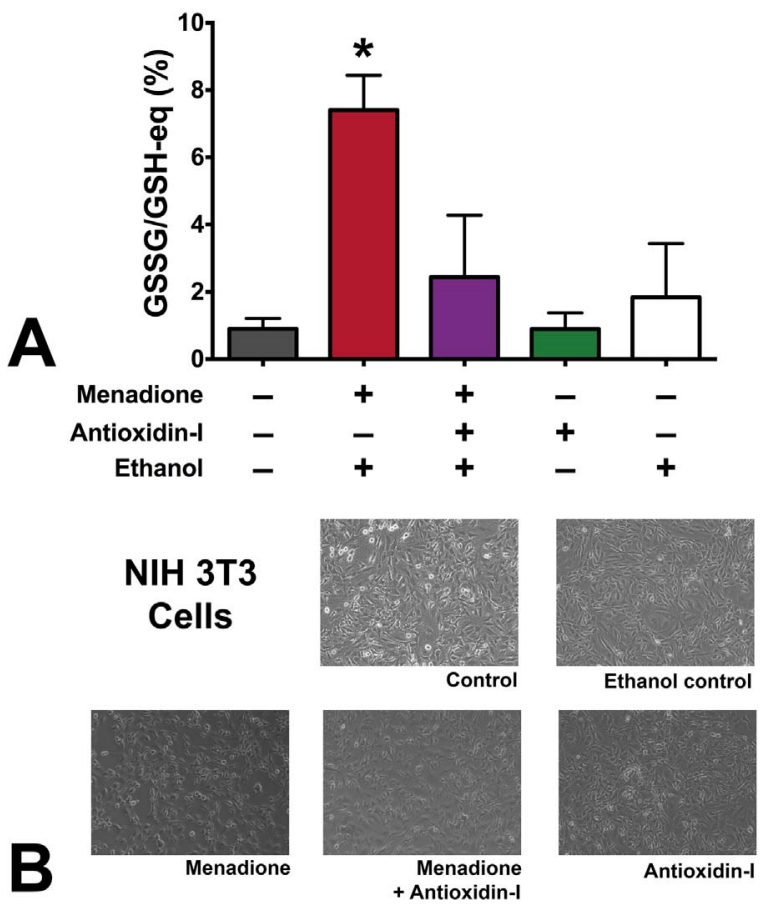

Fig. 7. (A) Redox status measured by GSSG/GSH-eq ratio and (B) morphology of murine fibroblasts NIH3T3 exposed to $20 \mu \mathrm{M}$ menadione, $400 \mu \mathrm{g} / \mathrm{mL}$ antioxidin or both. Additionally, an ethanol control (menadione vehicle) was assayed. The asterisk denotes significant difference in relation to all other groups. negative side effects because of fast tissue and blood clearance [69]. The bioprospection of this class of molecules is of great interest due to its wide applications in different industries, including cosmetics [70] or food industry to control lipid oxidation that produce undesirable offflavors and potentially toxic reactions products [71]. Moreover, they might also be used as leading templates for designing novel molecules for preventing neurodegeneration.

\section{Acknowledgments}

The authors thank of the B2Tech platform facilities (Biochemical And Biophysical Technologies, Instituto de Investigação e Inovação em Saúde (I3S) da Universidade do Porto, Portugal) for the use of circular dichroism (CD). AP is grateful for the Fundação para a Ciência e a Tecnologia (FCT, Portugal) grants (SFRH/BD/97995/2013) financed by POPH-QREN (subsidized by FSE and MCTES). NV thanks FCT and FEDER (European Union) for funding through UID/MULTI/04378/ 2013, project grant IF/00092/2014 and IF2014 position. NV thanks also Fundação Manuel António da Mota (FMAM, Portugal) by support to Nuno Vale Lab. PG thanks FCT for funding through UID/QUI/50006/ 2013. RS and CCP, hold postdoctoral fellowships from FCT (Refs: SFRH/BPD/91833/2012 and FRH/BPD/91962/2012, respectively). ACM is grateful to FAPESP (Grants 2014/02282-6 and 2016/18023-5). YPM is grateful to CNPq by the Senior Researcher Grant (PQ-Sr 306036/2016-9). EAB is grateful to PNPD/CAPES (Grant No:1603966) for its postdoctoral fellowship. M. M. Marani is a researcher at CONICET. 


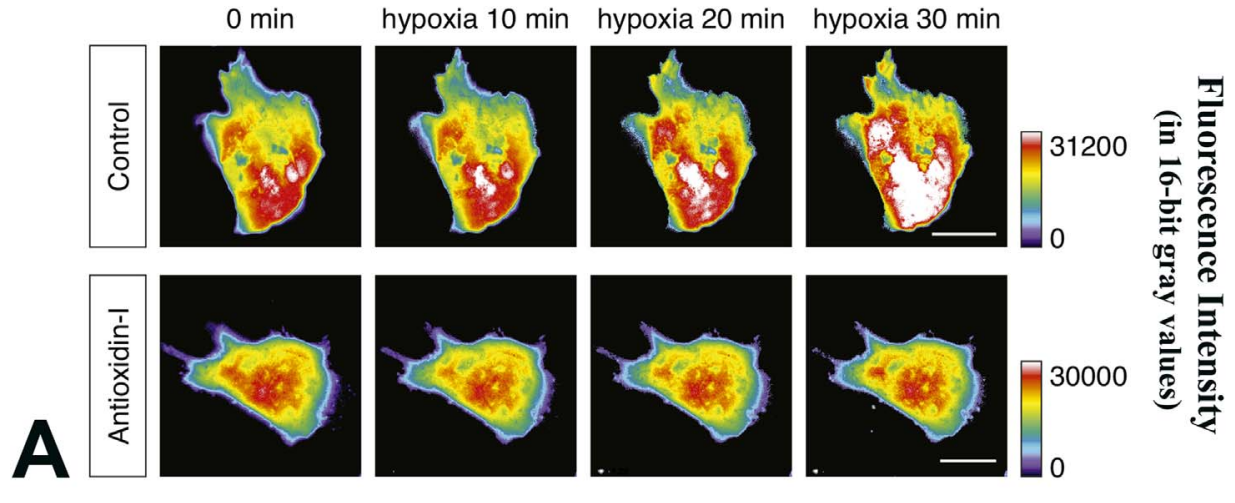

Fig. 8. Antioxidin-I prevents ROS generation induced by hypoxia in microglia. CHME3 human microglial cell cultures expressing the ROS biosensor (HyperRed; A and B) or the HSP-33 ROS FRET biosensor (C) were subjected to hypoxia in control saline (black lines) or in saline with $100 \mu \mathrm{M}$ antioxidin-I (red lines). Time-lapse fluorescence intensity changes for the HyperRed biosensor or fluorescence ratio changes for HSP biosensor (both normalized at 0 min) are shown $(n=4-7$ cells pooled across 2 different experiments). Scale bars, $10 \mu \mathrm{m}$. (For in terpretation of the references to color in this figure legend, the reader is referred to the web version of this article).

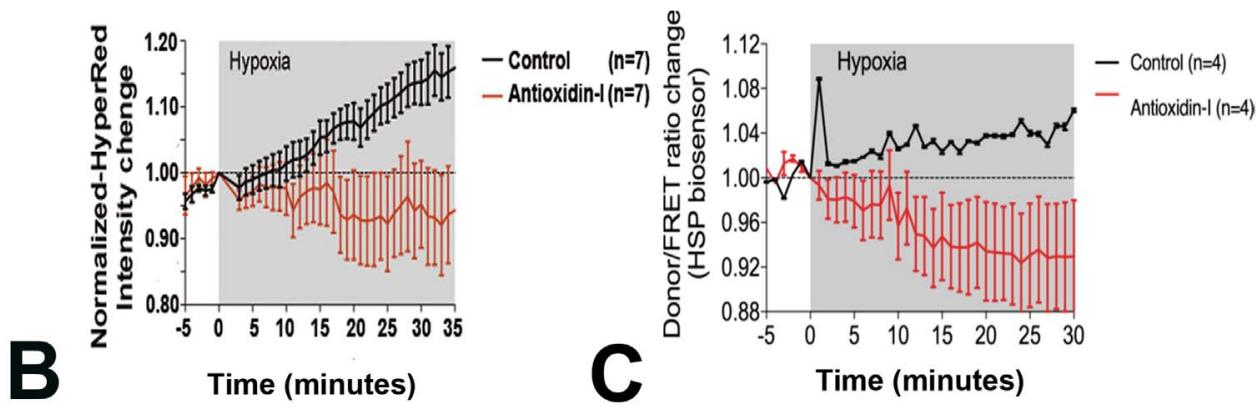

\section{References}

[1] B.T. Clarke, The natural history of amphibian skin secretions, their normal functioning and potential medical applications, Biol. Rev. 72 (1997) 365-379.

[2] M. Zasloff, Magainins, a class of antimicrobial peptides from Xenopus skin: isolation, characterization of two active forms, and partial cDNA sequence of a precursor, Proc. Natl. Acad. Sci. USA 84 (1987) 5449-5453.

[3] J.M. Conlon, Bradykinin and its receptors in non-mammalian vertebrates, Regul. Pept. 79 (1999) 71-81.

[4] X. Chen, L. Wang, H. Wang, H. Chen, M. Zhou, T. Chen, et al., A fish bradykinin (Arg0, Trp5, Leu8-bradykinin) from the defensive skin secretion of the European edible frog, Pelophylax kl. esculentus: structural characterization; molecular cloning of skin kininogen cDNA and pharmacological effects on mammalian smooth muscle, Peptides 32 (2011) 26-30, http://dx.doi.org/10.1016/j.peptides.2010.09.023.

[5] G. Mignogna, S. Pascarella, G. Amiconi, D. Barra, C. Wechselberger, C. Hinterleitner, et al., BSTI, a trypsin inhibitor from skin secretions of Bombina bombina related to protease inhibitors of nematodes, Protein Sci. 5 (2008) 357-362, http://dx.doi.org/10.1002/pro.5560050220.

[6] E.A. Barbosa, T. Iembo, G.R. Martins, L.P. Silva, M.V. Prates, A.C. Andrade, et al., Skin secretion peptides: the molecular facet of the deimatic behavior of the foureyed frog, Physalaemus nattereri (Anura, Leptodactylidae), Rapid Commun. Mass Spectrom. 29 (2015) 2061-2068, http://dx.doi.org/10.1002/rcm.7313.

[7] X. Xu, R. Lai, The chemistry and biological activities of peptides from amphibian skin secretions, Chem. Rev. 115 (2015) 1760-1846, http://dx.doi.org/10.1021/ cr4006704.

[8] A. Wolnicka-Glubisz, A. Pecio, D. Podkowa, L.M. Kolodziejczyk, P.M. Plonka, Pheomelanin in the skin of Hymenochirus boettgeri (Amphibia: anura: Pipidae), Exp. Dermatol. 21 (2012) 537-540, http://dx.doi.org/10.1111/j.1600-0625.2012. 01511.x.

[9] H. Yang, X. Wang, X. Liu, J. Wu, C. Liu, W. Gong, et al., Antioxidant peptidomics reveals novel skin antioxidant system, Mol. Cell. Proteom. 8 (2009) 571-583, http://dx.doi.org/10.1074/mcp.M800297-MCP200.

[10] C. Guo, Y. Hu, J. Li, Y. Liu, S. Li, K. Yan, et al., Identification of multiple peptides with antioxidant and antimicrobial activities from skin and its secretions of Hylarana taipehensis, Amolops lifanensis, and Amolops granulosus, Biochimie 105 (2014) 192-201, http://dx.doi.org/10.1016/j.biochi.2014.07.013.

[11] X. Wang, S. Ren, C. Guo, W. Zhang, X. Zhang, B. Zhang, et al., Identification and functional analyses of novel antioxidant peptides and antimicrobial peptides from skin secretions of four East Asian frog species, Acta Biochim. Biophys. Sin. 49 (2017) 550-559, http://dx.doi.org/10.1093/abbs/gmx032.

[12] C. Liu, J. Hong, H. Yang, J. Wu, D. Ma, D. Li, et al., Frog skins keep redox

homeostasis by antioxidant peptides with rapid radical scavenging ability, Free Radic. Biol. Med. 48 (2010) 1173-1181, http://dx.doi.org/10.1016/j. freeradbiomed.2010.01.036.

[13] B. Halliwell, J.M.C. Gutteridge, Free Radicals in Biology and Medicine, Oxford University Press, 2015, http://dx.doi.org/10.1093/acprof:oso/9780198717478. 001.0001/acprof-9780198717478.

[14] W. Dröge, Free radicals in the physiological control of cell function, Physiol. Rev. 82 (2002) 47-95, http://dx.doi.org/10.1152/physrev.00018.2001.

[15] L.A. Sena, N.S. Chandel, Physiological roles of mitochondrial reactive oxygen species, Mol. Cell. 48 (2012) 158-167, http://dx.doi.org/10.1016/j.molcel.2012.09. 025.

[16] H. Sies, Hydrogen peroxide as a central redox signaling molecule in physiological oxidative stress: oxidative eustress, Redox Biol. 11 (2017) 613-619, http://dx.doi. $\operatorname{org} / 10.1016 /$ j.redox.2016.12.035.

[17] P. Hernansanz-Agustín, A. Izquierdo-Álvarez, F.J. Sánchez-Gómez, E. Ramos, T. Villa-Piña, S. Lamas, et al., Acute hypoxia produces a superoxide burst in cells, Free Radic. Biol. Med. 71 (2014) 146-156, http://dx.doi.org/10.1016/j. freeradbiomed.2014.03.011.

[18] E.T. Chouchani, V.R. Pell, E. Gaude, D. Aksentijević, S.Y. Sundier, E.L. Robb, et al., Ischaemic accumulation of succinate controls reperfusion injury through mitochondrial ROS, Nature 515 (2014) 431-435, http://dx.doi.org/10.1038/ nature13909.

[19] A. van der Vliet, Y.M.W. Janssen-Heininger, Hydrogen peroxide as a damage signal in tissue injury and inflammation: murderer, mediator, or messenger? J. Cell. Biochem. 115 (2014) 427-435, http://dx.doi.org/10.1002/jcb.24683.

[20] S. Di Meo, T.T. Reed, P. Venditti, V.M. Victor, Role of ROS and RNS sources in physiological and pathological conditions, Oxid. Med. Cell. Longev. 2016 (2016), http://dx.doi.org/10.1155/2016/1245049 (1245049-44).

[21] S.S. Hardas, R. Sultana, A.M. Clark, T.L. Beckett, L.I. Szweda, M.P. Murphy, et al., Oxidative modification of lipoic acid by HNE in Alzheimer disease brain, Redox Biol. 1 (2013) 80-85, http://dx.doi.org/10.1016/j.redox.2013.01.002.

[22] L. Hou, X. Zhou, C. Zhang, K. Wang, X. Liu, Y. Che, et al., NADPH oxidase-derived $\mathrm{H}_{2} \mathrm{O}_{2}$ mediates the regulatory effects of microglia on astrogliosis in experimental models of Parkinson's disease, Redox Biol. 12 (2017) 162-170, http://dx.doi.org/ 10.1016/j.redox.2017.02.016.

[23] K.L. Berggren, J. Chen, J. Fox, J. Miller, L. Dodds, B. Dugas, et al., Neonatal iron supplementation potentiates oxidative stress, energetic dysfunction and neurodegeneration in the R6/2 mouse model of Huntington's disease, Redox Biol. 4 (2015) 363-374, http://dx.doi.org/10.1016/j.redox.2015.02.002.

[24] D. Martins, A.M. English, SOD1 oxidation and formation of soluble aggregates in yeast: relevance to sporadic ALS development, Redox Biol. 2 (2014) 632-639, http://dx.doi.org/10.1016/j.redox.2014.03.005.

[25] W.E. Duellman, A.B. Marion, S.B. Hedges, Phylogenetics, classification, and biogeography of the treefrogs (Amphibia: anura: Arboranae), Zootaxa 4104 (2016) 1-109, http://dx.doi.org/10.11646/zootaxa.4104.1.1.

[26] A. Sebben, Microdissecação fisiológica a fresco: uma nova visão sobre a anatomia de anfíbios e répteis, in: Herpetologia No Brasil, 2007, pp. 311-325.

[27] W. Kohn, L.J. Sham, Self-consistent equations including exchange and correlation effects, Phys. Rev. 140 (1965) A1133-A1138, http://dx.doi.org/10.1103/PhysRev. 
140.A1133.

[28] C. Lee, W. Yang, R.G. Parr, Development of the Colle-Salvetti correlation-energy formula into a functional of the electron density, Phys. Rev. B 37 (1988) 785-789, http://dx.doi.org/10.1103/PhysRevB.37.785.

[29] A.D. Becke, A new mixing of Hartree-Fock and local density-functional theories, J. Chem. Phys. 98 (1993) 1372-1377, http://dx.doi.org/10.1063/1.464304.

[30] P.C. Hariharan, J.A. Pople, The influence of polarization functions on molecular orbital hydrogenation energies, Theor. Chim. Acta 28 (1973) 213-222, http://dx. doi.org/10.1007/BF00533485.

[31] Gaussian 09, Revision A.02, M.J. Frisch, G.W. Trucks, H.B. Schlegel, G.E. Scuseria, M.A. Robb, J.R. Cheeseman, G. Scalmani, V. Barone, G.A. Petersson, H. Nakatsuji, X. Li, M. Caricato, A. Marenich, J. Bloino, B.G. Janesko, R. Gomperts, B. Mennucci, H.P. Hratchian, J.V. Ortiz, A.F. Izmaylov, J. L. Sonnenberg, D. Williams-Young, F. Ding, F. Lipparini, F. Egidi, J. Goings, B. Peng, A. Petrone, T. Henderson, D. Ranasinghe, V.G. Zakrzewski, J. Gao, N. Rega, G. Zheng, W. Liang, M. Hada, M. Ehara, K. Toyota, R. Fukuda, J. Hasegawa, M. Ishida, T. Nakajima, Y. Honda, O. Kitao, H. Nakai, T. Vreven, K. Throssell, J.A. Montgomery Jr., J.E. Peralta, F. Ogliaro, M. Bearpark, J.J. Heyd, E. Brothers, K.N. Kudin, V.N. Staroverov, T. Keith, R. Kobayashi, J. Normand, K. Raghavachari, A. Rendell, J.C. Burant, S.S. Iyengar, J. Tomasi, M. Cossi, J.M. Millam, M. Klene, C. Adamo, R. Cammi, J.W. Ochterski, R.L. Martin, K. Morokuma, O. Farkas, J.B. Foresman, and D. J. Fox, Gaussian, Inc., Wallingford CT, 2016.

[32] Z. Wang, G. Wang, APD: the antimicrobial peptide database, Nucleic Acids Res. 32 (2004) D590-D592, http://dx.doi.org/10.1093/nar/gkh025.

[33] CLSI, Methods for Dilution Antimicrobial Susceptibility Tests for Bacteria That Grow Aerobically, 2012

[34] M.S. Gião, M.L. González-Sanjosé, M.D. Rivero-Pérez C I. Pereira, M.E Pintado, F.X. Malcata, Infusions of Portuguese medicinal plants: dependence of final antioxidant capacity and phenol content on extraction features, J. Sci. Food Agric. 87 (2007) 2638-2647, http://dx.doi.org/10.1002/jsfa.3023.

[35] V. Bondet, W. Brand-Williams, C. Berset, Kinetics and mechanisms of antioxidant activity using the DPPH free radical method, LWT - Food Sci. Technol. 30 (1997) 609-615, http://dx.doi.org/10.1006/fstl.1997.0240.

[36] M. del Mar Contreras, B. Hernández-Ledesma, L. Amigo, P.J. Martín-Álvarez I. Recio, Production of antioxidant hydrolyzates from a whey protein concentrate with thermolysin: optimization by response surface methodology, LWT - Food Sci. Technol. 44 (2011) 9-15, http://dx.doi.org/10.1016/j.lwt.2010.06.017.

[37] L.C. Green, D.A. Wagner, J. Glogowski, P.L. Skipper, J.S. Wishnok, S.R. Tannenbaum, Analysis of nitrate, nitrite, and [15N]nitrate in biological fluids, Anal. Biochem. 126 (1982) 131-138, http://dx.doi.org/10.1016/0003-2697(82) 90118-x.

[38] L. Marcocci, J.J. Maguire, M.T. Droy-Lefaix, L. Packer, The nitric oxide-scavenging properties of Ginkgo biloba extract EGb 761, Biochem. Biophys. Res. Commun. 201 (1994) 748-755

[39] I. Rahman, A. Kode, S.K. Biswas, Assay for quantitative determination of glutathione and glutathione disulfide levels using enzymatic recycling method, Nat. Protoc. 1 (2006) 3159-3165, http://dx.doi.org/10.1038/nprot.2006.378.

[40] N. Janabi, S. Peudenier, B. Héron, K.H. Ng, M. Tardieu, Establishment of human microglial cell lines after transfection of primary cultures of embryonic microglial cells with the SV40 large T antigen, Neurosci. Lett. 195 (1995) 105-108.

[41] C.C. Portugal, R. Socodato, T. Canedo, C.M. Silva, T. Martins, V.S.M. Coreixas, et al., Caveolin-1-mediated internalization of the vitamin C transporter SVCT2 in microglia triggers an inflammatory phenotype, Sci. Signal. 10 (2017) eaal2005, http:// dx.doi.org/10.1126/scisignal.aal2005.

[42] Y.G. Ermakova, D.S. Bilan, M.E. Matlashov, N.M. Mishina, K.N. Markvicheva, O.M. Subach, et al., Red fluorescent genetically encoded indicator for intracellular hydrogen peroxide, Nat. Commun. 5 (2014) 5222, http://dx.doi.org/10.1038/ ncomms6222.

[43] R. Socodato, C.C. Portugal, T. Canedo, I. Domith, N.A. Oliveira, R. Paes-deCarvalho, et al., c-Src deactivation by the polyphenol 3-O-caffeoylquinic acid abrogates reactive oxygen species-mediated glutamate release from microglia and neuronal excitotoxicity, Free Radic. Biol. Med. 79 (2015) 45-55, http://dx.doi.org/ 10.1016/j.freeradbiomed.2014.11.019.

[44] R. Socodato, C.C. Portugal, I. Domith, N.A. Oliveira, V.S.M. Coreixas, E.C. Loiola et al., c-Src function is necessary and sufficient for triggering microglial cell activation, Glia 63 (2015) 497-511, http://dx.doi.org/10.1002/glia.22767.

[45] R. Socodato, F.N. Santiago, C.C. Portugal, I. Domith, T.G. Encarnação, E.C. Loiola, et al., Dopamine promotes NMDA receptor hypofunction in the retina through D1 receptor-mediated Csk activation, Src inhibition and decrease of GluN2B phosphorylation, Sci. Rep. 7 (2017) 40912, http://dx.doi.org/10.1038/srep40912.

[46] R. Wang, Y. Lin, T. Chen, M. Zhou, L. Wang, C. Shaw, Molecular cloning of a novel tryptophyllin peptide from the skin of the orange-legged monkey frog, Phyllomedusa hypochondrialis, Chem. Biol. Drug Des. 83 (2014) 731-740, http://dx.doi.org/10. 1111 /cbdd.12287.

[47] D. Vanhoye, F. Bruston, P. Nicolas, M. Amiche, Antimicrobial peptides from hylid and ranin frogs originated from a 150-million-year-old ancestral precursor with a conserved signal peptide but a hypermutable antimicrobial domain, Eur. J. Biochem. 270 (2003) 2068-2081.

48] G.D. Brand, J.R.S.A. Leite, L.P. Silva, S. Albuquerque, M.V. Prates, R.B. Azevedo, et al., Dermaseptins from Phyllomedusa oreades and Phyllomedusa distincta. AntiTrypanosoma cruzi activity without cytotoxicity to mammalian cells, J. Biol. Chem. 277 (2002) 49332-49340, http://dx.doi.org/10.1074/jbc.M209289200.

[49] G.D. Brand, F.C. Krause, L.P. Silva, J.R.S.A. Leite, J.A.T. Melo, M.V. Prates, et al., Bradykinin-related peptides from Phyllomedusa hypochondrialis, Peptides 27 (2006) 2137-2146, http://dx.doi.org/10.1016/j.peptides.2006.04.020.

[50] G.D. Brand, R.C. Santos, L.M. Arake, V.G. Silva, L.M.C. Veras, V. Costa, et al., The skin secretion of the amphibian Phyllomedusa nordestina: a source of antimicrobial and antiprotozoal peptides, Molecules 18 (2013) 7058-7070, http://dx.doi.org/10. 3390/molecules18067058.

[51] Y. Song, S. Ji, W. Liu, X. Yu, Q. Meng, R. Lai, Different expression profiles of bioactive peptides in Pelophylax nigromaculatus from distinct regions, Biosci. Biotechnol. Biochem. 77 (2013) 1075-1079, http://dx.doi.org/10.1271/bbb. 130044.

[52] H. Yu, X. Qiao, J. Gao, C. Wang, S. Cai, L. Feng, et al., Identification and characterization of novel antioxidant peptides involved in redox homeostasis of frog, Limnonectes fragilis, Protein Pept. Lett. 22 (2015) 776-784.

[53] N. Rajapakse, E. Mendis, W.-K. Jung, J.-Y. Je, S.-K. Kim, Purification of a radical scavenging peptide from fermented mussel sauce and its antioxidant properties, Food Res. Int. 38 (2005) 175-182, http://dx.doi.org/10.1016/j.foodres.2004.10. 002 .

[54] H.-M. Chen, K. Muramoto, F. Yamauchi, K. Fujimoto, K. Nokihara, Antioxidative properties of histidine-containing peptides designed from peptide fragments found in the digests of a soybean protein, J. Agric. Food Chem. 46 (1998) 49-53, http:/ dx.doi.org/10.1021/jf970649w.

[55] E. Mendis, N. Rajapakse, H.-G. Byun, S.-K. Kim, Investigation of jumbo squid (Dosidicus gigas) skin gelatin peptides for their in vitro antioxidant effects, Life Sci 77 (2005) 2166-2178, http://dx.doi.org/10.1016/j.lfs.2005.03.016.

[56] A.T. Girgih, R. He, S. Malomo, M. Offengenden, J. Wu, R.E. Aluko, Structural and functional characterization of hemp seed (Cannabis sativa L.) protein-derived antioxidant and antihypertensive peptides, J. Funct. Foods 6 (2014) 384-394, http:// dx.doi.org/10.1016/j.jff.2013.11.005

[57] B. Ou, M. Hampsch-Woodill, R.L. Prior, Development and validation of an improved oxygen radical absorbance capacity assay using fluorescein as the fluorescent probe, J. Agric. Food Chem. 49 (2001) 4619-4626, http://dx.doi.org/10.1021/jf010586o.

[58] D. Huang, B. Ou, M. Hampsch-Woodill, J.A. Flanagan, R.L. Prior, High-throughput assay of oxygen radical absorbance capacity (ORAC) using a multichannel liquid handling system coupled with a microplate fluorescence reader in 96-well format, $\mathrm{J}$. Agric. Food Chem. 50 (2002) 4437-4444, http://dx.doi.org/10.1021/jf0201529.

[59] M.M. Marani, F.S. Dourado, P.V. Quelemes, A.R. de Araujo, M.L.G. Perfeito, E.A. Barbosa, et al., Characterization and biological activities of ocellatin peptides from the skin secretion of the frog Leptodactylus pustulatus, J. Nat. Prod. 78 (2015) 1495-1504, http://dx.doi.org/10.1021/np500907t.

[60] F.Q. Schafer, G.R. Buettner, Redox environment of the cell as viewed through the redox state of the glutathione disulfide/glutathione couple, Free Radic. Biol. Med. 30 (2001) 1191-1212, http://dx.doi.org/10.1016/S0891-5849(01)00480-4.

[61] L. Flohé, The fairytale of the GSSG/GSH redox potential, Biochim. Biophys. Acta 1830 (2013) 3139-3142, http://dx.doi.org/10.1016/j.bbagen.2012.10.020.

[62] C. Berndt, C.H. Lillig, L. Flohé, Redox regulation by glutathione needs enzymes, Front. Pharmacol. 5 (2014) 168, http://dx.doi.org/10.3389/fphar.2014.00168.

[63] E.A. Bordt, B.M. Polster, NADPH oxidase- and mitochondria-derived reactive oxygen species in proinflammatory microglial activation: a bipartisan affair? Free Radic. Biol. Med. 76 (2014) 34-46, http://dx.doi.org/10.1016/j.freeradbiomed. 2014.07.033.

[64] A.I. Rojo, G. McBean, M. Cindric, J. Egea, M.G. López, P. Rada, et al., Redox control of microglial function: molecular mechanisms and functional significance, Antioxid. Redox Signal. 21 (2014) 1766-1801, http://dx.doi.org/10.1089/ars.2013.5745.

[65] G. Solaini, A. Baracca, G. Lenaz, G. Sgarbi, Hypoxia and mitochondrial oxidative metabolism, Biochim. Biophys. Acta 2010 (1797) 1171-1177, http://dx.doi.org/10. 1016/j.bbabio.2010.02.011.

[66] G.A. Donnan, M. Fisher, M. Macleod, S.M. Davis, Stroke, Lancet 371 (2008) 1612-1623, http://dx.doi.org/10.1016/S0140-6736(08)60694-7.

[67] R. Brouns, P.P. De Deyn, The complexity of neurobiological processes in acute ischemic stroke, Clin. Neurol. Neurosurg. 111 (2009) 483-495, http://dx.doi.org/10 1016/j.clineuro.2009.04.001.

[68] H.J. Forman, K.J.A. Davies, F. Ursini, How do nutritional antioxidants really work: nucleophilic tone and para-hormesis versus free radical scavenging in vivo, Free Radic. Biol. Med. 66 (2014) 24-35, http://dx.doi.org/10.1016/j.freeradbiomed. 2013.05.045.

[69] B.H. Sarmadi, A. Ismail, Antioxidative peptides from food proteins: a review, Peptides 31 (2010) 1949-1956, http://dx.doi.org/10.1016/j.peptides.2010.06.020.

[70] L. Zhang, C. Zhang, R. Gao, R. Yang, Q. Song, Sequence based prediction of antioxidant proteins using a classifier selection strategy, PLoS One 11 (2016) e0163274, http://dx.doi.org/10.1371/journal.pone.0163274.

[71] P.-J. Park, W.-K. Jung, K.-S. Nam, F. Shahidi, S.-K. Kim, Purification and characterization of antioxidative peptides from protein hydrolysate of lecithin-free egg yolk, J. Am. Oil Chem. Soc. 78 (2001) 651-656, http://dx.doi.org/10.1007/ s11746-001-0321-0. 